Review

\title{
HBV and HCV Therapy
}

\section{Pietro Lampertico*, Alessio Aghemo, Mauro Viganò and Massimo Colombo}

“A.M. Migliavacca” Center for Liver Disease, First Gastroenterology Unit, Fondazione IRCCS Maggiore Hospital, Mangiagalli e Regina Elena, Università di Milano, Via F. Sforza 35, 20122 Milan, Italy

* Author to whom correspondence should be addressed; E-Mail: pietro.lampertico@unimi.it; Tel.: +39-2550-35432; Fax: +39-2503-20410.

Received: 13 August 2009; in revised form: 8 October 2009 / Accepted: 19 October 2009 / Published: 22 October 2009

\begin{abstract}
One year of interferon therapy inhibits HBV replication in one third of the patients whereas long-term administration of oral nucleos(t)ide analogues is efficient in most of them, as long as early treatment adaptation in patients with partial virological response and resistance is provided. Following the demonstration of a more potent antiviral effect in terms of sustained virological response (SVR) rates, Pegylated-IFN coupled with Ribavirin has become the standard treatment for chronic hepatitis C, with nearly $65 \%$ of all treated patients achieving a SVR. Long-term suppression of HBV and eradication of HCV would halt the progression of chronic hepatitis to cirrhosis, hepatocellular carcinoma and liver decompensation.
\end{abstract}

Keywords: HBV DNA; nucleos(t)ide analogues; Peg-IFN; resistance; HCV RNA; Ribavirin; SVR

\section{Treatment of Chronic Hepatitis B}

Chronic hepatitis B viral infection affects about 400 million people around the globe, being one of the most common infectious diseases and among the world's leading causes of death. Antiviral therapy of chronic hepatitis B (CHB) aims to improve quality of life and survival chance of the patients by preventing progression of liver damage to cirrhosis, end-stage liver disease and liver cancer (HCC), thus preventing anticipated liver-related death. This goal is achieved by suppression of HBV 
replication in a sustained or maintained manner, either by short-term "curative" treatment with standard (IFN) and pegylated interferon (Peg-IFN) or long-term "suppressive" therapy with nucleos(t)ide analogues, like lamivudine, adefovir, entecavir, telbivudine and tenofovir. Since both strategies have advantages and disadvantages, the wise treatment of a patient with $\mathrm{CHB}$ requires careful balance between prediction of the natural history of HBV and of the potential benefit of antiHBV therapy. Recent data on the long-term efficacy of third generation of nucleos(t)ide analogues entecavir and tenofovir have tipped the balance towards long-term suppression therapy as the first-line option for most patients with $\mathrm{CHB}$, independent of the HBeAg status.

\subsection{Treatment Indications}

Patients with clinical or histological predictors of HBV progression should be prioritized to antiHBV treatment [1-3]. HBeAg seropositive immunotolerant patients with persistently normal alaninoaminotransferase (ALT) levels, high serum HBV DNA, minimal histological changes in the liver and no family history of HCC or cirrhosis, do not require immediate therapy. Inactive HBV carriers, i.e. HBsAg/anti-HBe seropositive patients with persistently normal ALT levels and less than $2000 \mathrm{IU} / \mathrm{ml}$ of serum HBV DNA, do not require therapy, as well as patients with slightly elevated ALT (less than 2 times the upper limit of normal) and histological hepatitis less than grade A2 or stage F2 by METAVIR scoring.

According to the recent EASL Practice Guidelines [3], both HBeAg-positive and HBeAg-negative patients should be considered for treatment when HBV DNA levels exceed $2000 \mathrm{IU} / \mathrm{ml}$ and/or the serum ALT levels are above the upper limit of normal (ULN), and a liver biopsy shows moderate to severe active necro-inflammation and/or fibrosis, i.e. grade A2 or stage F2 by METAVIR scoring. While indications for treatment must also take into account age, health status, and availability of antiviral agents in individual countries, current guidelines support also the view that all patients with compensated or decompensated cirrhosis and detectable serum HBV DNA (even $<2000 \mathrm{IU} / \mathrm{ml}$ ) must receive antiviral treatment regardless of ALT. The main goal of treatment in these severely ill patients is to completely inhibit viral replication in order to improve liver function and survival and, in case of liver transplantation, to prevent graft re-infection.

\subsection{End-points of Therapy}

The treatment paradigm of CHB is to persistently suppress serum HBV DNA to as low a level as possible. This goal can be obtained either on- or off-treatment, with subsequent biochemical remission, histological improvement, prevention of complications and improved long-term outcomes. Maintenance of undetectable levels of HBV DNA is mandatory to prevent resistance to NUCs and increase the rates of anti-HBe and $\mathrm{HBsAg}$ seroconversion. In both $\mathrm{HBeAg}$-positive and $\mathrm{HBeAg}$ negative patients, the ideal end-point of therapy is sustained HBsAg loss with seroconversion to antiHBs [4-6]. In HBeAg-positive patients, a sustained HBeAg seroconversion is a realistic and satisfactory end-point associated with improved prognosis [7-9]. In HBeAg-positive patients unable to seroconvert to anti-HBe and in HBeAg-negative patients, a maintained undetectable HBV DNA level on treatment with NUCs or a sustained undetectable HBV DNA level after IFN is the next most 
desirable end-point, as the induction of persistent biochemical and virological remission appears to be the most important therapeutic target in CHB [10-16].

\subsection{Therapeutic Strategies}

Currently, there are seven drugs licensed for treatment of CHB: standard interferon (IFN $\alpha$ ),

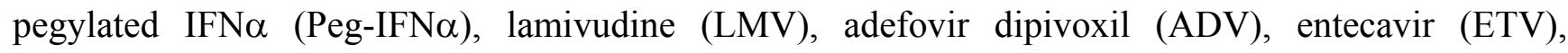
telbivudine (LdT) and tenofovir disoproxil fumarate (TDF). IFN couples antiviral and immunomodulatory activities and is administered subcutaneously, whereas the oral antiviral agents which are analogs of natural nucleosides (LMV, ETV, LdT) or nucleotides (ADV, TDF) are administered once daily. Two different therapeutic approaches can be used: short-term finite curative treatment based upon IFN administration and long-term suppressive treatment based upon NUC therapy.

\subsubsection{HBeAg-positive Chronic Hepatitis B}

Treatment with IFN: In a minority of HBeAg-positive CHB, standard IFN $\alpha$ for 4-6 months or PegIFN $\alpha$ for 12 months can induce sustained off-treatment response. Following the administration of 5 million units (MU) daily or $10 \mathrm{MU}$ thrice weekly of standard IFN or $180 \mu \mathrm{g}$ Peg-IFN $\alpha$-2a or $100 \mu \mathrm{g}$ Peg-IFN $\alpha-2 b$ per week, $25 \%$ of the HBeAg positive patients have had virological response in terms of HBeAg seroconversion, while HBsAg seroconversion occurred in 3\% of the patients 6 months offtreatment [17-19] (Figure 1). Most patients may have a sustained treatment response, in association with a high likelihood of HBsAg loss [9]. After a 3-year post treatment follow-up, 37\% and $11 \%$ of the patients who received Peg-IFN $\alpha-2 b$ for 1 year became HBeAg and HBsAg seronegative, respectively, and among the initial responders, $\mathrm{HBeAg}$ and $\mathrm{HBsAg}$ were lost in $81 \%$ and $30 \%$ of the patients, respectively [20]. HBe seroconversion was more likely to occur in patients with high ALT (above 3 times ULN), low HBV DNA (below $7 \mathrm{log} I \mathrm{U} / \mathrm{ml}$ ) and high activity scores ( $\geq$ A2) on liver biopsy [17]. An HBV DNA decrease to less than 20,000 IU/ml at week 12 of IFN treatment is associated with a $50 \%$ chance of $\mathrm{HBeAg}$ seroconversion [21]. Patients with genotype A and B have a good end of treatment and off- treatment responses to IFN, with $\mathrm{HBeAg}$ loss occurring in one third of the patients, in addition to HBsAg seroconversion in $13 \%-22 \%$ of genotype A patients [22,23].

Additional therapy with NUCs will cause a more robust decline of HBV DNA levels without increasing the chances of sustained virological responses to IFN [18,19]. Despite increased risks of side effects and contraindications, a 48 -week course of Peg-IFN $\alpha$ is a recommended as a first-line therapy for young, highly motivated, non-cirrhotic HBeAg-positive patients with genotype A or B having high pre-treatment serum levels of ALT [3].

Treatment with NUCs: NUCs are potent antiviral agents affecting the reverse transcription step of HBV replication. Finite duration treatment with NUCs is achievable for HBeAg-positive patients with undetectable HBV DNA $(<10-15 \mathrm{IU} / \mathrm{ml})$ and HBeAg seroconversion on treatment. The duration of therapy, however, is unpredictable depending on timing of HBeAg seroconversion. Patients lacking HBeAg seroconversion require long-term treatment with NUCs. Despite being well tolerated, longterm administration of NUCs is hampered by the selection of drug resistant mutants, leading to loss of efficacy, frequent relapse after discontinuation and by concern on long-term safety. Although anti- 
HBV potency of various NUCs may not be directly comparable because of the heterogeneity of assays used in the registration trials, substantial differences in the potency of antiviral agents in reducing serum HBV DNA levels have surfaced. Notwithstanding, differences in anti-HBV activity do not translate into different rates of $\mathrm{HBeAg}$ seroconversion, at least within the first year of therapy. The virological response rates at year one were $36 \%-40 \%, 21 \%, 67 \%, 60 \%$ and $74 \%$ with lamivudine, adefovir, entecavir, telbivudine and tenofovir, respectively, while the HBe seroconversion rates were approximately 20\% for all NUCs (Figure 1) [24-29].

Figure 1. 48-week rates of virological response (HBV DNA $<300 / 400$ copies $/ \mathrm{ml}$ ) and HBeAg seroconversion in NUC-naïve HBeAg-positive patients. Collation of currently available data - not from head-to-head studies.
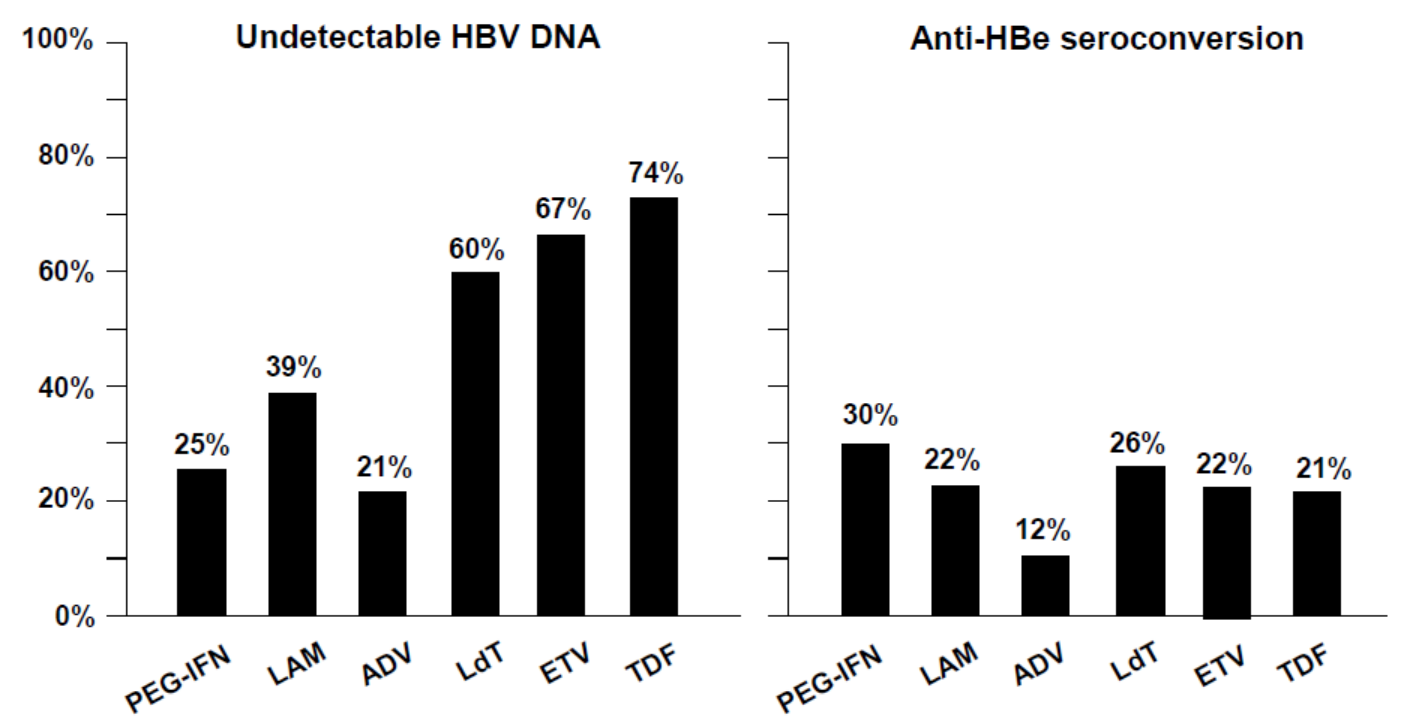

Adapted from EASL HBV Guidelines, J Hepatol 2009

$\mathrm{HBeAg}$ seroconversion increases steadily with prolonged LMV treatment, reaching $27 \%, 40 \%$, $47 \%$ and $50 \%$ at year 2, 3, 4 and 5, respectively [30,31] but long-term LMV monotherapy inexorably ends with the selection of resistant strains harbouring specific mutations in the HBV polymerase gene, i.e. $\mathrm{M} 204 \mathrm{I} / \mathrm{V}$ as a primary mutation and L80, L180M, V173L as the most relevant secondary mutations [32-35], at rates that increase from $20 \%$ after 1 year to peaks of $70 \%$ after 5 years of drug therapy $[31,36]$. Non-Asian ethnicity, high pre-treatment serum HBV DNA level, male sex, and high body mass index are well recognized predictors of LMV resistance [37]. Since the risk of developing LMVresistance directly correlates with a slow response of serum HBV DNA at month 6, incomplete suppression of HBV replication seems to play a key role in the generation of mutated strains $[38,39]$. Following LMV therapy, the durability of HBeAg seroconversion appears to be smaller when compared to IFN, being $77 \%$ at 3 years in non-Asian patients and less than $60 \%$ at 2 years in Asian patients, however following shorter courses of therapy [40-42]. To overcome HBeAg seroreversion, LMV should be continued probably for an additional year. Prolonged LMV therapy may reduce the risk of disease progression and development of HCC [43], except in patients developing LMVresistance. Indeed, the beneficial effects of LMV appear to be offset by the development of 
LMV-resistance to the point that recent current guidelines do not recommend LMV use anymore [3]. Prolonged therapy with ADV resulted in an increase of HBeAg seroconversion rates to 29\% and 43\% at year 2 and 3 [44], with a marginal genotypic resistance of $6 \%$. Durability of HBeAg seroconversion may be as high as $90 \%$ in the absence of any serious adverse event [44]. The anti-HBV activity of ETV monotherapy results in a continuous viral decline beyond week 48 , similarly to the rates of $\mathrm{HBeAg}$ seroconversion $[45,46]$, in the presence of limited rates $(1.2 \%$ at year 5$)$ of resistance in NUCnaïve patients [47]. The same observation holds true for TDF: two-year treatment achieved HBV DNA $<400$ copies $/ \mathrm{ml}$ in $78 \%$ of patients with $30 \%$ and $6 \%$ of $\mathrm{HBeAg}$ and $\mathrm{HBsAg}$ loss, respectively [48]. Even though the antiviral potency expressed by the reduction in serum HBV DNA levels differs among the various anti-HBV agents (highest with TDF, ETV and LdT, intermediate with LMV and lowest with IFN $/$ Peg-IFN $\alpha$ and ADV), these differences do not translate into different $\mathrm{HBeAg}$ seroconversion rates, at least within the first year of therapy. HBsAg loss is $<2 \%$ after one year of treatment with NUCs, mimicking the natural history of the infection in the untreated patients.

Pre-treatment factors, predictive of $\mathrm{HBeAg}$ seroconversion following NUCs, included low viral load (HBV DNA below $7 \log _{10} \mathrm{IU} / \mathrm{ml}$ ), high serum ALT levels (above 3 times ULN) and high activity scores at liver biopsy (at least A2) [49]. During treatment with LMV, ADV or LdT, an undetectable HBV DNA by a real-time PCR assay at 24 or 48 weeks is associated with a reduced risk of resistance and an improved chance of a $\mathrm{HBeAg}$ seroconversion, without any influence of the HBV genotype $[24,39]$.

\subsubsection{HBeAg-negative Chronic Hepatitis B}

Treatment with IFN: Twelve to 24-month courses with IFNa (3 or 5 MU thrice weekly) resulted in sustained long-term off therapy responses in less than one third of patients who often $(>40 \%)$ cleared HBsAg $(10-12,50]$. As sustained responses increased with treatment duration, HBsAg went lost in up to $67 \%$ of patients under long term follow-up [12]. In a large multinational trial with Peg-IFN $\alpha-2 \mathrm{a} \pm$ LMV versus LMV monotherapy for 48 weeks, a biochemical and virological response was achieved in $35 \%$ of the patients treated with Peg-IFN [51]. Although combination of Peg-IFN $\alpha-2 a$ and LMV led to higher end of treatment response rates than either drug alone, this effect went lost 6 months after treatment cessation. Viral response to IFN therapy was predicted by high baseline ALT and low HBV DNA levels, female gender, younger age and HBV genotype [52]. Sustained off-therapy response, however, tapered down during follow-up, with $<10,000$ copies/ml HBV DNA being detected in a quarter of patients treated with Peg-IFN $\alpha-2 \mathrm{a} \pm \mathrm{LMV}$, while $9 \%$ of the patients in both groups lost HBsAg [53]. According to EASL Practice Guidelines, Peg-IFN is indicated to treat HBeAg-negative patients with the best chance of a sustained off treatment response [3].

Treatment with NUC: Short-term treatment with NUCs results in high on-therapy rates of virological responses in HBeAg-negative CHB: $72 \%, 51 \%, 90 \%, 88 \%$ and $91 \%$ with lamivudine, adefovir, entecavir, telbivudine and tenofovir, respectively, however with a high risk of relapse after treatment discontinuation, indicating the need for continuous administration of these agents [54-63] (Figure 2). 
Figure 2. 48-week rates of virological response (HBV DNA $<300 / 400$ copies $/ \mathrm{ml}$ ) in NUC-naïve HBeAg-negative patients. Collation of currently available data - not from head-to-head studies.

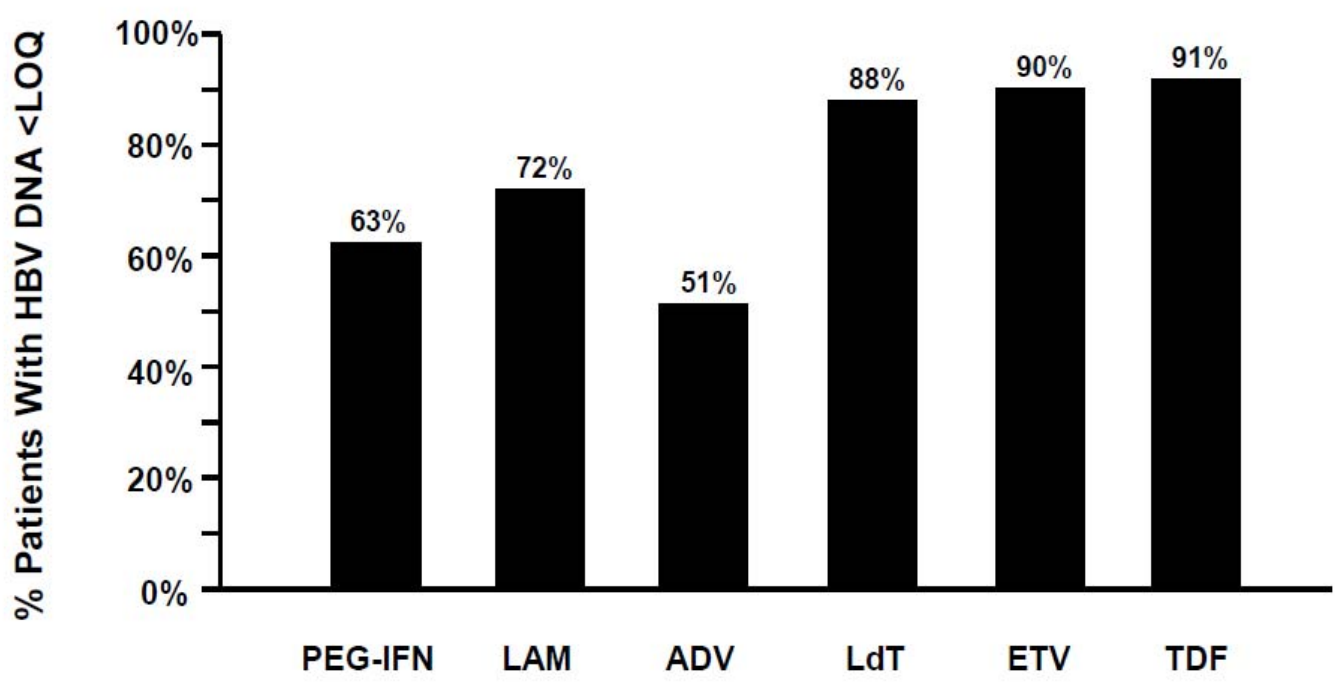

Adapted from EASL HBV Guidelines, J Hepatol 2009

In patients achieving viral remission, disease prognosis is overall favourably affected, even though development of viral resistance may jeopardize long term outcome of hepatitis due to virological and biochemical breakthrough, requiring rescue treatment [3,15,16] (Figure 3).

According to recent current guidelines, LMV monotherapy is no longer the recommended first-line strategy of therapy [3]. ADV monotherapy is no longer considered a first-line therapy either, since the proportion of patients with HBV DNA $<1000$ copies/ml and normal ALT levels is $67 \%$ and $69 \%$, respectively, at year 5 of therapy [58]. In the face of few patients (5\%) with a HBsAg loss, ADV monotherapy faces the risk of genotypic resistance, virological resistance (defined as $>1 \log$ rebound compared to on-treatment nadir) and clinical resistance (defined as virological and biochemical rebounds), which are $29 \%, 20 \%$ and $11 \%$. Drug withdrawal in patients with persistent undetectable HBV DNA by PCR assays results in a virological relapse occurrence in all patients, although approximately $70 \%$ of them could maintain serum levels of HBV DNA below 10,000 copies and ALT levels within the normal range for at least 12-18 months [59]. Most of the few patients evaluated for 2 or 3 years on ETV treatment, had maintained virological response [60,61]. Despite the lack of longterm resistance data in $\mathrm{HBeAg}$ negative patients, the very low rates of resistance in $\mathrm{HBeAg}$ positive partial responders indicate that ETV monotherapy suppresses viral replication in most $\mathrm{HBeAg}$ negative patients for years [47]. In a 2-year study of LdT $600 \mathrm{mg} /$ day, $82 \%$ of the nucleoside-naïve HBeAg-negative patients achieved undetectable HBV DNA by PCR assay [62], with genotypic resistance to LdT developing in $9 \%$ of the patients. A 24-week virologic response (HBV DNA $<2$ or $3 \log$ copies/ml) correlated with high rates of maintained PCR undetectability and negligible risk of LdT resistance after 2 years of therapy [63]. This data provides the rationale for adapting and tailoring antiviral therapy in 24 -week suboptimal responders. The nucleotide analog TDF 
is a powerful anti-HBV drug, as shown by the 2-year study in which $91 \%$ of patients achieved HBV DNA $<400$ copies/ml and most normalized ALT levels [64].

In HBeAg-negative patients, combination of two NUCs, as well as the use of Peg-IFN plus NUC, have so far not proven to be beneficial for providing better treatment outcome, however, combination as de novo treatment may prevent resistance. Long-term treatment with the most potent drugs with the optimal resistance profile, i.e. TDF or ETV, should be used as first-line monotherapy in HBeAgnegative patients who cannot benefit from interferon [3]. However, the long-term effects, safety and tolerability of ETV and TDF are still unknown.

Figure 3. Incidence of resistance in NUC-naïve patients treated up to 5 years. Collation of currently available data - not from head-to-head studies.

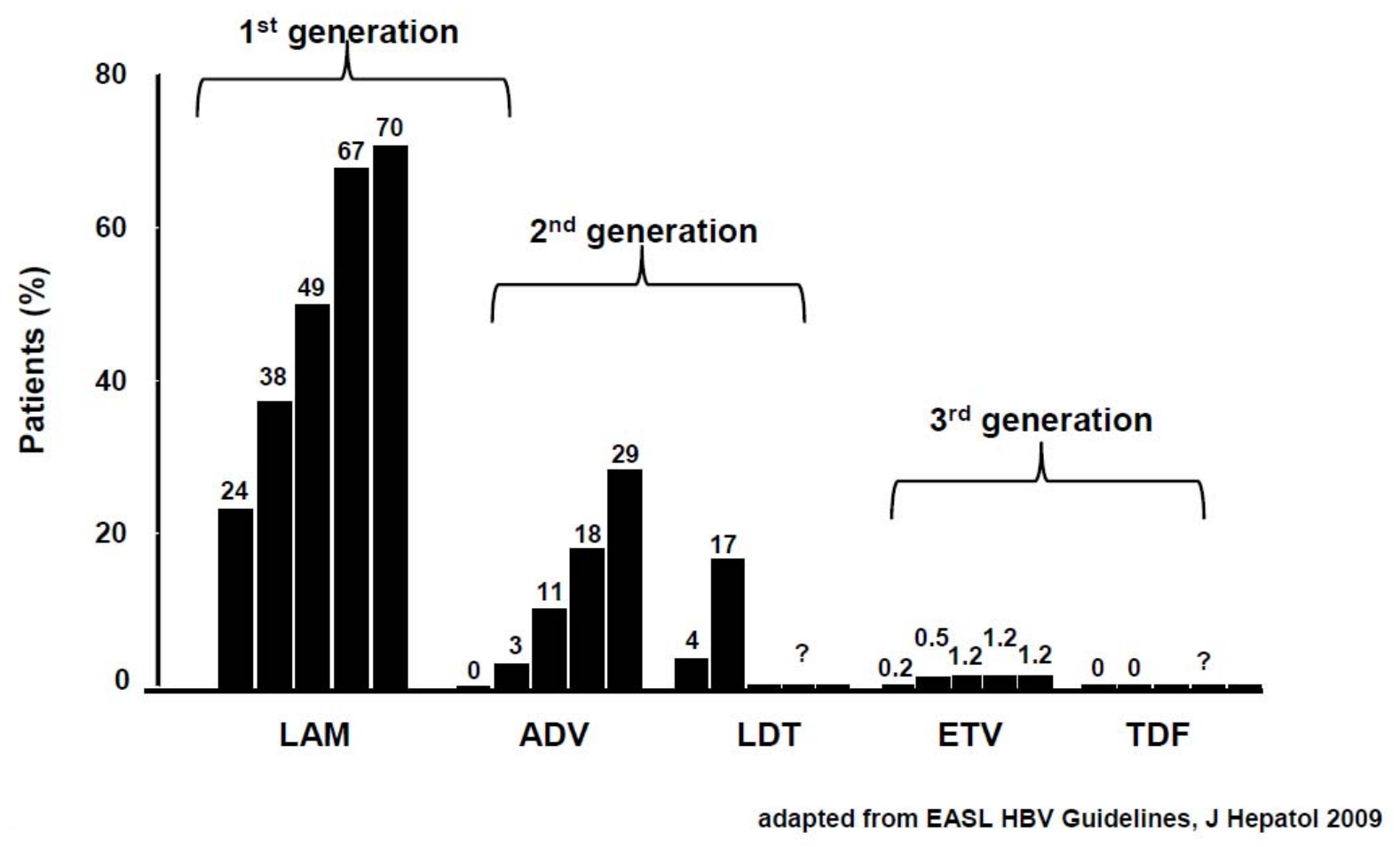

\subsection{Management of Treatment Failure}

Working against long-term therapy with NUCs is the risk of the emergence of drug resistant HBV strains, ultimately leading to treatment failure and liver disease progression (Figure 3). Being the drug for rescuing a response to therapy selected on the basis of its in vitro cross resistance profile, NUC like LdT and ETV are unfit for treating LMV-R, since they share a similar resistance profile, characterized by the mutation in position 204 plus several compensatory mutations [65]. By converse, being the resistance pattern of the nucleotide analog ADV based upon changes at position 236 and 181, i.e. $\mathrm{N} 23 \mathrm{~T}$ and $\mathrm{A} 181 \mathrm{~V}$, this drug is an option for treating LMV-R strains [66-68]. As a general rule, a nucleotide analog is recommended to rescue for $\mathrm{HBV}$ resistance in patients resisting to nucleoside analogues, whereas a nucleoside analog is recommended for a nucleotide-related resistance. EASL Practice Guidelines recommend TDF as the nucleotide of first choice for the rescue of nucleoside resistant strains of HBV [3]. Following selection of a rescue drug, the next step is to define whether to 
treat the patients with a monotherapy, i.e. by switching from LMV to ADV or TDF or other drugs, or with a combination therapy ("add-on" strategy). Both approaches have pros and contras: the former strategy is cheaper but potentially less efficacious, while the latter is more expensive and of unproven safety, but potentially more effective in the long-term [69-72]. A 2-year "add-on" treatment with $\mathrm{LMV}+\mathrm{ADV}$ of $74 \mathrm{LMV}-\mathrm{R}$ HBeAg-negative patients resulted in no patient developing either a virological breakthrough or a genotypic resistance to ADV, enforcing the rationale for LMV+ADV combo therapy of LMV-R patients [73]. Combo therapy with LMV+ADV was demonstrated to be efficient in HBeAg-positive, HIV-confected patient developing LAM-R too, and in HBeAg-positive, genotype C infected, LMV-R patients in Japan [74,75]. Recently, an update to the original studies reported $90 \%$ rates of PCR negativity and $<1 \%$ of cumulative incidence of ADV resistance in LMV-R patients receiving combo therapy $[69,76,77]$. Selection of timing for a rescue with ADV+LMV is of strategic importance in the management of LMV-R, as a complete virological response was achieved in all patients with baseline HBV DNA below $6 \log _{10} \mathrm{cp} / \mathrm{mL}$ compared to only $75 \%$ of those with baseline viremia between 6 and $8 \quad \log _{10} \mathrm{cp} / \mathrm{mL}$ and $50 \%$ of those with higher than $8 \log _{10} \mathrm{cp} / \mathrm{mL}$ viral load [73]. Early rescue prevented ALT reactivation too, compared to patients starting on therapy at higher levels of viremia who required more than 18 months of therapy to achieve disease remission [73]. Since hepatitis flares boost clinical decompensation in patients with cirrhosis, early "add-on" is mandatory in critically ill patients with LMV-R. The increased efficacy of early "add-on" rescue therapy, when compared with the late one, made of it now a recommended strategy for LMV-R patients, in order to also minimize the risk of multiple drug-resistant selection [78].

\subsection{Prevention of Resistance}

Resistance to anti-HBV analogues can be delayed or prevented by careful selection of patients to be treated, administration of de novo combination therapy, use of third generation NUCs as first line therapy and early adaptation of antiviral therapy, especially in partial responders. In the search for predictors of resistance to improve the cost-effectiveness of HBV therapy, a relationship between residual viral load at week 24 and risk of developing resistance at week 48 or 96, has been demonstrated [71]. According to the EASL Practice Guidelines, partial virological responders (PVR) to NUCs have a more than $1 \log$ decline of viremia compared to baseline but still detectable serum levels of HBV DNA by real-time PCR assay (>10-15 U/ml) at week 24 or 48, depending on the genetic barrier of the anti-HBV drug [3].

The clinical relevance of NUCs PVR relates to the high risk these patients face of developing resistance to long-term anti-HBV treatment, particularly when first (LMV) and second generation (LdT, ADV) drugs are involved [3]. Conversely, for PVR to third generation NUCs, like ETV and TDF, though carrying a lower risk of resistance to long-term monotherapy, the association between residual viremia at week 48 and secondary treatment failure during follow-up has not been fully established [3]. Despite the strong rationale for adapting antiviral therapy, at least for selected NUCs, evidence-based algorithms for rescuing these patients have not been generated, apart from expert opinions. 
Patients with undetectable HBV DNA at week 24 of LMV or LdT have a negligible (5\%) risk of LMV-R in the following 18 months. LMV and LdT therefore should be continued as monotherapy only in those patients who achieve undetectable HBV DNA at week 24, provided that a regular HBV DNA monitoring is established to early identify the emergence of resistance and start an appropriate rescue strategy [39,79]. Patients with a detectable viremia at week 24 are at high risk of developing LMV and LdT resistance and, therefore, require early adaptation of antiviral therapy by either switching to a more potent antiviral agent or adding-on to another analog with a different resistance profile. Due to the lack of studies comparing these two strategies, either independently or head-tohead, an evidence-based indication cannot be offered on how patients with a PVR to LMV or LdT should be treated. To further reduce the yield of PVR at week 24, EASL Guidelines recommend LdT to be started as monotherapy in those patients with baseline viremia below $6 \log _{10} \mathrm{IU} / \mathrm{ml}$, only. For patients on ADV monotherapy, PVR at week 48 has been associated to a 50\% chances of developing resistance in the following 3 years, suggesting, therefore, a rescue therapy for all PCR positive patients to prevent resistance [3]. De novo combination might represent the best approach for highly viremic patients in order to increase the antiviral efficacy while rescuing the risk of resistance, as suggested by studies in HIV patients. In general, the best strategy to prevent resistance is to start with potent and high genetic barrier drugs like ETV and TDF, which are expected to carry a negligible risk of drug resistance in clinical practice in the long term.

\section{Treatment of Chronic Hepatitis C}

Chronic hepatitis $\mathrm{C}$ is a major worldwide health problem with an estimated prevalence of 1.6-2\% [80,81]. In Europe, more than 9 million chronic carriers and approximately 86,000 deaths per year are estimated due to the late complications of hepatitis C virus (HCV)[82]. The prognosis of chronic hepatitis $\mathrm{C}$ depends on the rate of fibrosis progression, which over a 20-30 year time span, may determine the risk of developing cirrhosis and its complications, namely HCC, liver decompensation, hepatic encephalopathy and oesophageal variceal bleeding [83]. The only therapeutic intervention able to halt this progressive process is eradication of HCV by Interferon (IFN)-based therapies.

Since the empirical choice to use IFN in 1986, therapy for chronic hepatitis C has constantly evolved over the past decade, with the attainable sustained virological response (SVR) rates increasing through the years [84] (Figure 4). The addition of the guanosine nucleoside analogue ribavirin (Rbv) to IFN can be considered the major breakthrough in the treatment of chronic hepatitis $C[85,86]$. Through mechanisms of action that still remain largely unknown [87], Rbv has determined a greater number of patients to ultimately achieve a SVR by increasing the rates of on-treatment response and reducing the rates of post-treatment relapse. In the large phase III clinical trials designed to assess its efficacy and safety, the combination of IFN and Rbv resulted in SVR rates of 30-35\% in HCV genotype 1 patients and $75-80 \%$ in HCV-2 and 3 patients. These figures exceeded by far those obtained by IFN monotherapy, effectively leading the way for combination therapy to become the standard of care in the late 1990's [85,86]. The latest innovation in the treatment of chronic hepatitis $\mathrm{C}$ has been the pegylation of the IFN molecule (PegIFN) through the attachment of one or more polyethylene glycols to the IFN, a process that is able to modify the immunological, pharmacokinetic and pharmacodynamic properties of the drug [88]. Standard IFN was in fact characterized by a number of limitations, such as 
poor stability, short elimination half-life and potential immunogenicity, that ultimately determined its small antiviral effect $[89,90]$. Moreover, due to the increase in elimination half-life obtained by the pegylation process, it has been possible to lengthen the dosing interval from the unpractical three times a week schedule required by standard IFN, to the more "user friendly" once a week administration, a feature that has increased convenience whilst facilitating adherence to the recommended treatment schedule. Following the demonstration of a more potent antiviral effect in terms of SVR rates in phase III randomized trials [91,92], PegIFN has become the standard of care for chronic hepatitis C. Currently, two forms of pegylated IFN exist: PegIFNa2a (Pegasys ${ }^{\circledR}$; Hoffmann-LaRoche, Basel, Switzerland) and PegIFNa2b (PegIntron ${ }^{\circledR}$; Schering-Plough, Kenilworth, NJ, USA), which show significant differences in terms of pharmacokinetics and dynamics, that ultimately might translate into different efficacy rates [93-99].

Figure 4. Attainable sustained virological response (SVR) rates to anti-HCV treatment.

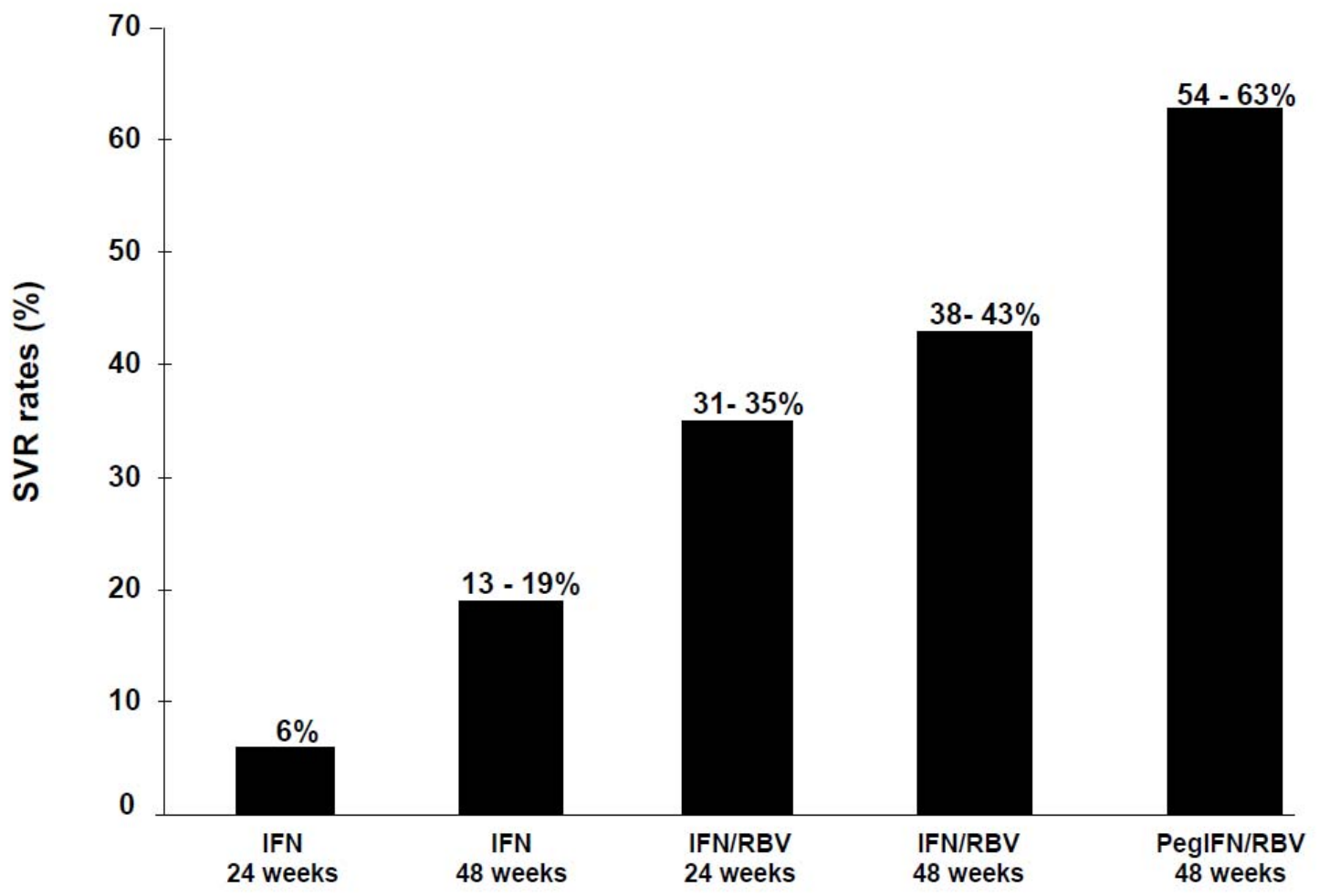

\subsection{From registration trials to optimization studies}

The superiority of combination therapy with PegIFN and Rbv was demonstrated by 2 international randomized multicenter studies [91,92]. In the PegIFNa2b trial by Manns et al., the overall SVR rates achieved by the PegIFN/Rbv treatment arm were significantly higher than those obtained with standard IFN/Rbv (PegIFNa2b 54\% vs. IFNa2b 47\%), even if the benefit was restricted to patients infected by HCV genotype 1 (PegIFNa2b 42\% vs. IFNa2b 33\%). Quite surprisingly, in fact, this was not the case for patients with HCV genotypes 2 and 3 where the use of PegIFN did not translate into any apparent increase in SVR rates (PegIFNa2b 82\% vs. IFNa2b 79\%). On the contrary, in the PegIFN $\alpha 2$ a trial by Fried et al., PegIFN $\alpha 2 a / R b v$ combination therapy resulted in significantly higher 
SVR rates in all HCV genotypes compared to standard IFN/Rbv (HCV-1: 46\% vs. 36\%, HCV-2 and 3: $76 \%$ vs. 61\%). These data effectively led PegIFN plus Rbv combination therapy to supplant standard IFN as the standard of care treatment for naïve patients with chronic hepatitis C. Still, some limitations in the design of both studies required further multicenter trials, the so called optimization studies, to effectively determine the optimal dosing for each HCV genotype patient. In the study by Manns and colleagues, PegIFNa2b was administered coupled with a fixed dose of Rbv ( $800 \mathrm{mg} /$ day), that clearly was underdosed, especially for patients with high body weight and HCV genotype 1. This was clearly shown by the Win-R study that demonstrated the superiority of the weight based dosing of Rbv over the fixed dose in patients with HCV genotype 1 [100]. Moreover, the Manns study could not assess the optimal treatment duration, since all patients were treated for 48 weeks independently from $\mathrm{HCV}$ genotype. The formal demonstration that patients with HCV-2 and HCV-3 can be successfully treated with a shorter course of combination therapy ( 24 weeks) was provided by the study by Zeuzem et al. in 2004. In that study, where HCV-2 and HCV-3 patients were treated for 24 weeks and compared with the patients treated for 48 weeks in the Manns study database, SVR rates were $79-93 \%$ in the 24 week treatment schedule and $88 \%$ for the 48 week historical control group [101]

For PegIFNa2a combination therapy, we have to thank the Hadziyannis study for providing us clinicians with a better individualized treatment schedule. In fact, the study clearly demonstrated that 48 weeks of treatment were better in terms of SVR rates than 24 weeks for patients with HCV-1, and that the higher dosing of Rbv, i.e. $1000 \mathrm{mg}$ /day for those weighing less than $75 \mathrm{~kg}$ and $1200 \mathrm{mg} / \mathrm{day}$ for those weighing more than $75 \mathrm{~kg}$, was associated with higher SVR rates than the fixed dose of Rbv (800 mg/day) (52\% vs. 41\%). On the contrary, the same study showed that for patients with HCV-2 or $\mathrm{HCV}-3$, 24 weeks of combination therapy with a low dose of Rbv (800 mg) were sufficient to maximise treatment efficacy. Another noteworthy finding of the registration studies was the discovery of the so called HCV RNA week 12 stopping rule for HCV-1 patients. To that date, in fact, treatment was continued until week 24 in all patients, and therapy eventually discontinued in those who still tested serum positive for HCV RNA, the so called non responders. In the attempt to identify an earlier time point for stopping antiviral therapy, Fried and co-workers retrospectively identified in HCV RNA testing at week 12 the key time-point: a less than 2 Log decline in HCV RNA at this time point compared to baseline values was in fact highly predictive of a non-SVR, with only $3 \%$ of those patients ultimately achieving a SVR. This "stopping rule" was later validated also for PegIFNa2b [102], effectively leading the way for the study of early kinetics of HCV-RNA to become the standard of care in clinical practice in the years to follow [103]. Table 1 shows the recommended treatment schedules for naïve patients with chronic hepatitis $\mathrm{C}$. 
Table 1. Recommended treatment schedules for naïve patients with chronic hepatitis C.

\section{Genotype} Peg-IFN dose

Daily Ribavirin Dose

Duration

Stopping Rule

HCV-1/4

PegIFN $\alpha 2 a 180 \mu \mathrm{g} /$ week

$1000 \mathrm{mg}$ if $<75 \mathrm{~kg} ; 1200 \mathrm{mg}$ if $\geq 75 \mathrm{~kg}$

48 weeks

$12^{\circ}$ or $24^{\circ}$ week if $\mathrm{NR}^{*}$

PegIFNa2b $1.5 \mu \mathrm{g} / \mathrm{kg} /$ week

$800 \mathrm{mg}$ if $<65 \mathrm{~kg} ; 1000 \mathrm{mg}$ if $\geq 65 \mathrm{~kg}$ and $\leq 85 \mathrm{~kg}$ $1200 \mathrm{mg}$ if $>85 \mathrm{~kg}$ and $\leq 105 \mathrm{~kg} ; 1400 \mathrm{mg}$ if $>105 \mathrm{~kg}$

48 weeks $12^{\circ}$ or $24^{\circ}$ week if $\mathrm{NR}^{*}$
24 weeks

24 weeks
PegIFN $\alpha 2 b 1.5 \mu \mathrm{g} / \mathrm{kg} /$ week

$800 \mathrm{mg}$ if $<65 \mathrm{~kg} ; 1000 \mathrm{mg}$ if $\geq 65 \mathrm{~kg}$ and $\leq 85 \mathrm{~kg}$

$1200 \mathrm{mg}$ if $>85 \mathrm{~kg}$ and $\leq 105 \mathrm{~kg} ; 1400 \mathrm{mg}$ if $>105 \mathrm{~kg}$

* NR (Non Response): less than $2 \log \mathrm{HCV}-\mathrm{RNA}$ decline at week 12 or HCV-RNA detectability at week 24 of treatment 


\subsection{Towards Individualization of Antiviral Therapy}

The Hadziyannis study should now be viewed as the first attempt to individualize anti-HCV therapy, anticipating the idea that SVR rates and tolerability can be maximized by customized schedules of treatment more than by a single "one for all" treatment regimen. Further efforts towards more refined individualized schedules were spurred by the growing evidence that the chances of achieving a SVR were related to the rapidity of serum HCV RNA clearance, SVR rates in fact being higher and relapse rates being lower in patients achieving HCV RNA negativity at week 4, the so called rapid virological response (RVR), than in any other subgroup of patients [104]. As a matter of fact, a small pilot study from Norway showed that patients infected with HCV-2 and HCV-3 who had achieved HCV-RNA undetectability at week 4 and 8 could successfully be treated with PegIFNa2b and Rbv given for just 14 weeks [105].

These findings coupled with the poor tolerability profile of PegIFN/Rbv combination therapy led researchers to analyze if shorter treatment periods could be an option for patients who achieved an RVR. The study by Zeuzem et al. in 2006 was the first to assess this matter in HCV-1 infected patients. 235 Patients with low baseline HCV-RNA values $(<800,000 \mathrm{IU} / \mathrm{mL})$ were treated with PegIFN $\alpha 2 b$ for 24 weeks and compared to an historical control arm, once again derived from the Manns study [106]. While the SVR rates were significantly lower in the 24 week treatment arm compared to the standard 48 week schedule (50\% vs. $71 \%$ ), if only patients with an RVR were analyzed, SVR rates did not differ between the 2 treatment groups ( $89 \%$ vs. $85 \%)$. Unfortunately, the study was not completely bias free as the primary end-point was not met and the efficacy data of the 24 week schedule in patients with an RVR derive from a subgroup analysis. Moreover, the lack of a true control arm in that study cannot be completely overlooked; still these data should be viewed as the first scientific proof that shorter treatment durations can be considered for this subset of patients. By retrospectively analyzing the data from the Hadziyannis study, Jensen and co-workers confirmed these findings also for the PegIFNa2a-based combination therapy in patients with an RVR. In fact, SVR rates were $89 \%$ in the $51 \mathrm{HCV}-1$ patients treated for 24 weeks and $77 \%$ in those treated for 48 weeks [107]. Altogether these data have led the EMEA to approve the 24 week treatment schedule of PegIFN 2 2a/2b plus Rbv for naïve HCV-1 patients with a low baseline viremia achieving an RVR.

The same paradigm was then also applied to patients with HCV-2 and HCV-3, a subgroup known to achieve SVR rates of approximately $70-80 \%$ with the standard of care 24 week schedule of PegIFN plus Rbv therapy. Multiple studies which addressed whether an abbreviated treatment regimen to 1216 weeks could be proposed to the many HCV-2 and HCV-3 patients who achieved an RVR unfortunately differ significantly in terms of design, type of PegIFN utilized and Rbv dosing [108111]. Taken altogether, these studies demonstrate that, first of all, an abbreviated treatment schedule should be proposed only to patients who achieve an RVR, as SVR rates are dismal if this end-point is not reached [110]. Secondly, what has consistently emerged is that while these abbreviated schedule strategies achieve high SVR rates, these are somewhat lower than those obtained by the standard 24 treatment schedules due to the higher relapse rate. The recently published non-inferiority study by Dalgard et al. further added to this, since while SVR rates in HCV-2 and HCV-3 patients with an RVR treated with PegIFNa2b/Rbv for 14 weeks were similar to those obtained with the standard 24 
treatment course ( $81 \%$ vs $91 \%)$, the non-inferiority end-point was not met, effectively demonstrating that a shorter treatment course is inferior to the standard schedule [112]. Further working against an indiscriminate use of abbreviated therapies in patients with easy to cure HCV genotypes are the findings of a study in Italy showing increased risk of post-treatment relapse in patients with advanced fibrosis or high baseline body weight [113]. In conclusion, the jury on the efficacy of abbreviated therapies in HCV-2 and HCV-3 patients with an RVR is still out, the most reasonable approach being that abbreviated therapies should not be the standard of care for all HCV-2 and HCV-3 patients, but should only be considered in those who are intolerant to the standard 24 week duration [103].

Also unresolved is the issue regarding extended treatment duration in $\mathrm{HCV}-1$ naïve patients with a delayed virologic response, defined as HCV RNA clearance between week 12 and 24 of treatment. These patients are characterized by high rates of post-treatment relapse, that were lowered by the extended treatment duration in at least 3 studies. In the Berg study the SVR rates in these patients were $29 \%$ in the 72 weeks extended treatment duration arm and $17 \%$ in the standard treatment group. The higher SVR rates were the direct consequence of lower relapse rates (40\% vs. $64 \%)$ more than higher ETR rates (49\% vs. 47\%) [114]. The same was true for another study conducted utilizing PegIFNa2b $1.5 \mathrm{mcg} / \mathrm{kg}$ plus weight based Rbv in the same HCV-1 slowly responsive patients [115]. While these data suggest that if antiviral therapy is well-tolerated prolonged therapy to 72 weeks may be a viable option in this subset of patients [103], a recent multicenter randomized study showed no benefit of the extended treatment duration in HCV-1 slow responder patients [116]. In our opinion, these contrasting data coupled with the increase in terms of costs and side effects deriving from extending treatment duration to 72 weeks, suggest that this therapeutic strategy needs to be further validated before it can be implemented in the therapeutic algorithm of patients with chronic hepatitis $\mathrm{C}$.

\subsection{Retreatment of Persons Who Failed to Respond to a Previous Treatment}

Roughly $20-50 \%$ of all treated patients will fail to achieve a SVR to IFN based therapies as a consequence of either primary non-response during treatment or post-treatment relapse following therapy discontinuation. In the wait for new more potent anti-HCV drugs that in theory should reduce the rates of treatment failure [117], effective strategies need to be developed for the retreatment of these patients, since most often treatment failure is observed in those who are most in need of anti$\mathrm{HCV}$ treatment, i.e. those with advanced fibrosis. If the previous treatment consisted of standard IFN only, recent data show that the chance a SVR with PegIFN $22 \mathrm{a}$ or $\alpha 2 \mathrm{~b}$ plus Rbv is roughly $20 \%$ to $40 \%[118,119]$. However, if the patient already received Rbv combined with either IFN or PegIFN, SVR rates are extremely low being close to $10 \%$ and $5 \%$, respectively $[118,119]$. Due to the disappointing rates obtained, the recent AASLD guidelines do not recommend the re-treatment with PegIFN plus Rbv of these patients [103]. While this certainly is the most evidence based approach, there are patients that cannot wait 2-3 years to be retreated with the new direct anti-HCV drugs either due to an advanced disease or a sense of urgency to start a re-treatment. Recent data suggest that a 72 week treatment course of PegIFN $\alpha 2$ a plus Rbv, both at standard dosage, might be the best therapeutic option in patients who have previously non responded to a course of PegIFNa2b plus Rbv [120]. The recently published REPEAT study, originally designed to assess the efficacy of 12 week 360 $\mathrm{mcg} /$ week PegIFNa2a plus weight based Rbv induction dose, followed by either 60 or 36 weeks of 
standard therapy, compared to the standard $180 \mathrm{mcg} /$ week PegIFN $\alpha 2 \mathrm{a}$ dose with weight based Rbv in patients who failed a previous PegIFNa2b plus Rbv course, showed that the patients treated for 72 weeks achieved significantly higher SVR rates compared to those who received 48 weeks (16\% vs. $8 \%, \mathrm{p}<0.001$ ), with no apparent benefit from the $360 \mathrm{mcg} /$ week PegIFN $\alpha 2 \mathrm{a}$ induction dose. While the study enrolled too few patients with HCV genotypes 2 and 3 to draw any definite conclusions about the predictive role of HCV genotype on treatment outcome, bridging fibrosis/cirrhosis emerged once again as a strong predictor of treatment failure in the study. SVR rates in this subgroup of patients in fact were lower than $5 \%$, effectively suggesting that the re-treatment of these patients should currently be deferred.

The study also demonstrated that antiviral treatment should be stopped in those patients who do not achieve HCV RNA negativity at week 12, since SVR in this subset was achieved in 4\% of the patients independently from the treatment duration. While the overall observed $12 \%$ SVR rate is less than astounding, the demonstration of the superiority of the 72 week PegIFN $\alpha 2$ a plus Ribavirin treatment arm led the EMEA to approve this regimen in previous non-responsive patients.

\section{Conclusions}

The management of chronic hepatitis B has evolved fast, several therapeutic options are now available and nowadays hepatitis B is a treatable disease. Therapy must reduce HBV DNA to as low a level as possible to ensure a degree of virological suppression that will then lead to biochemical remission, histological improvement and prevention of disease progression. IFN and NUC have both advantages and disadvantages, short-term treatment with Peg-IFN induces a sustained virological response in a third of patients, long-term NUCs treatment inhibits HBV replication in most of the patients, but drug resistance and safety in the long-term will remain the most important unresolved questions. Careful evaluation of patient history, staging of liver disease and virological factors should guide the start of treatment and the choice to the most appropriate treatment strategy. Antiviral therapy with third generation NUC such as TDF and ETV, early adaptation of therapeutic strategy in patients with partial virological response or treatment failure have significantly improved the long-term suppression rates, providing complete inhibition of HBV replication in the majority of patients for at least 5 years.

Currently, nearly $65 \%$ of all treated patients with chronic hepatitis $\mathrm{C}$ obtain persistent HCV viral eradication following PegIFN ( $\alpha 2 \mathrm{a}$ or $\alpha 2 \mathrm{~b}$ ) plus Rbv combination therapy. While in the past years clinical research efforts have been geared toward individualizing treatment schedules on the basis of pre-treatment and on-treatment predictors of treatment outcome, the recent technical advances in cell culture systems and replication assays have finally provided researchers and pharmaceutical industries with the tools to develop and study new antiviral drugs in the treatment of chronic hepatitis $\mathrm{C}$. These new drugs are particularly needed in patients who have failed to respond to a previous course of IFN plus Rbv, as the currently achievable SVR rates are far from being satisfactory. Many antiviral compounds have been evaluated for their efficacy in treating HCV patients specific protease and polymerase inhibitors are currently the most promising drugs being tested, with Telaprevir and Boceprevir recently entering Phase III studies. Both drugs have shown potent antiviral activity both in vitro and in vivo, however emerging as poor candidates for monotherapy due to the early emergence of 
drug resistant viral strains. This has forced researchers to focus on a triple therapy regimen, resulting from the combination of these drugs with PegIFN plus Rbv [121,122]. PegIFN and Rbv have in fact emerged as essential counterparts to reduce drug resistance and ultimately achieve persistent viral suppression, de facto reinforcing the concept that PegIFN and RBV will likely remain the backbone of antiviral therapy for years to come.

\section{References and Notes}

1. Lok, A.S.; McMahon, B.J. Chronic hepatitis B. Hepatology 2007, 45, 507-539.

2. Liaw, Y.F.; Leung, N.; Guan, R.; Lau, G.K.; Merican, I.; McCaughan, G.; Gane, E.; Kao, J.H.; Omata, M.; Asian-Pacific consensus update working party on chronic hepatitis B. Asian-Pacific consensus statement on the management of chronic hepatitis B: a 2005 update. Liver Int. 2005, 25, 472-489.

3. European Association for the Study of the Liver. EASL Clinical Practice Guidelines: Management of chronic hepatitis B. J. Hepatol. 2009, 50, 227-242.

4. Fattovich, G. Natural history and prognosis of hepatitis B. Semin. Liver Dis. 2003, 23, 47-58.

5. Fattovich, G.; Bortolotti, F.; Donato, F. Natural history of chronic hepatitis B: special emphasis on disease progression and prognostic factors. J. Hepatol. 2008, 48, 335-352.

6. McMahon, B.J. The natural history of chronic hepatitis B virus infection. Semin. Liver Dis. 2004, 24, 17-21.

7. Hsu, Y.S; Chien, R.N.; Yeh, C.T.; Sheen, I.S.; Chiou, H.Y.; Chu, C.M.; Liaw, Y.F. Long-term outcome after spontaneous $\mathrm{HBeAg}$ seroconversion in patients with chronic hepatitis B. Hepatology 2002, 35, 1522-1527.

8. van Zonneveld M.; Honkoop P.; Hansen B.E.; Niesters H.G.; Darwish Murad S.; de Man R.A.; Schalm S.W.; Janssen H.L. Long-term follow-up of alpha-interferon treatment of patients with chronic hepatitis B. Hepatology 2004, 39, 804-810.

9. Niederau, C.; Heintges, T.; Lange, S.; Goldmann, G.; Niederau, C.M.; Mohr, L.; Häussinger, D. Long-term follow-up of HBeAg-positive patients treated with interferon alfa for chronic hepatitis B. N. Engl. J. Med. 1996, 334, 1422-1427.

10. Papatheodoridis, G.V.; Manesis, E.; Hadziyannis, S.J. The long-term outcome of interferon-alpha treated and untreated patients with HBeAg-negative chronic hepatitis B. J. Hepatol. 2001, 34, 306-313.

11. Brunetto, M.R.; Oliveri, F.; Coco, B.; Leandro, G.; Colombatto, P.; Gorin, J.M.; Bonino, F. Outcome of anti-HBe positive chronic hepatitis $\mathrm{B}$ in alpha interferon treated and untreated patients: a long term cohort study. J. Hepatol. 2002, 36, 263-270.

12. Lampertico, P.; Del Ninno, E.; Viganò, M.; Romeo, R.; Donato, M.F.; Sablon, E.; Morabito, A.; Colombo M. Long-term suppression of hepatitis B e antigen-negative chronic hepatitis B by 24month interferon therapy. Hepatology 2003, 37, 756-763.

13. Di Marco, V.; Lo Iacono, O.; Cammà, C.; Vaccaro, A.; Giunta, M.; Martorana, G.; Fuschi, P.; Almasio, P.L.; Craxì, A. The long term course of chronic hepatitis B. Hepatology 1999, 30, $257-$ 264. 
14. Bonino, F.; Brunetto, M.R. Chronic hepatitis B e antigen (HBeAg) negative, anti-HBe positive hepatitis B: an overview. J. Hepatol. 2003, 39, S160-S163.

15. Hadziyannis, S.J.; Papatheodoridis, G.V. Hepatitis B e antigen-negative chronic hepatitis B: natural history and treatment. Semin. Liver Dis. 2006, 26,130-141.

16. Di Marco, V.; Marzano, A.; Lampertico, P.; Andreone, P.; Santantonio, T.; Almasio, P.L.; Rizzetto, M.; Craxì, A.; Italian Association for the Study of the Liver (AISF) Lamivudine Study Group, Italy. Clinical outcome of HBeAg-negative chronic hepatitis B in relation to virological response to lamivudine. Hepatology 2004, 40, 883-891.

17. Wong, D.K.; Cheung, A.M.; O’Rourke, K.; Naylor, C.D.; Detsky, A.S.; Heathcote, J. Effect of alpha-interferon in patients with hepatitis B e antigen-positive chronic hepatitis B. A metaanalysis. Ann. Intern. Med. 1993, 119, 312-323.

18. Lau, G.K.; Piratvisuth, T.; Luo, K.X.; Marcellin, P.; Thongsawat, S.; Cooksley, G.; Gane, E.; Fried, M.W.; Chow, W.C.; Paik, S.W.; Chang, W.Y.; Berg, T.; Flisiak, R.; McCloud, P.; Pluck, N.; Peginterferon Alfa-2a HBeAg-Positive Chronic Hepatitis B Study Group. Peginterferon Alfa-2a, lamivudine, and the combination for HBeAg-positive chronic hepatitis B. N. Engl. J. Med. 2005, 352, 2682-2695.

19. Janssen, H.L.; van Zonneveld, M.; Senturk, H.; Zeuzem, S.; Akarca, U.S.; Cakaloglu, Y.; Simon, C.; So T.M.; Gerken, G.; de Man, R.A.; Niesters, H.G.; Zondervan, P.; Hansen, B.; Schalm, S.W.; HBV 99-01 Study Group; Rotterdam Foundation for Liver Research. Pegylated interferon alfa-2b alone or in combination with lamivudine for HBeAg-positive chronic hepatitis B: a randomised trial. Lancet 2005, 365, 123-129.

20. Buster, E.H.; Flink, H.J.; Cakaloglu, Y.; Simon, K.; Trojan, J.; Tabak, F.; So, T.M.; Feinman, S.V.; Mach, T.; Akarca, U.S.; Schutten, M.; Tielemans, W.; van Vuuren, A.J.; Hansen, B.E.; Janssen, H.L. Sustained HBeAg and HBsAg loss after long-term follow-up of HBeAg-positive patients treated with peginterferon alpha-2b. Gastroenterology 2008, 135, 459-467.

21. Fried, M.W.; Piratvisuth, T.; Lau, G.K.K.; Marcellin, P.; Chow, W.C.; Cooksley, G.; Luo, K.X.; Paik, S.W.; Liaw, Y.F.; Button, P.; Popescu, M. HBeAg and hepatitis B virus DNA as outcome predictors during therapy with peginterferon alfa-2a for $\mathrm{HBeAg}$-positive chronic hepatitis $\mathrm{B}$. Hepatology 2008, 47, 428-434.

22. Wai, C.T.; Chu, C.J.; Hussain, M.; Lok, A.S. HBV genotype B is associated with better response to interferon therapy in $\mathrm{HBe} \mathrm{Ag}(+)$ chronic hepatitis than genotype C. Hepatology 2002, 36, $1425-$ 1430.

23. Flink, H.J.; van Zonneveld, M.; Hansen, B.E.; de Man, R.A.; Schalm, S.W.; Janssen, H.L. Treatment with Peg-interferon alpha-2b for HBeAg-positive chronic hepatitis B: HBsAg loss is associated with HBV genotype. Am. J. Gastroenterol. 2006, 101, 297-303.

24. Lai, C.L.; Chien, R.N.; Leung, N.W.; Chang, T.T.; Guan, R.; Tai, D.I.; Ng, K.Y.; Wu, P.C.; Dent, J.C.; Barber, J.; Stephenson, S.L.; Gray, D.F. A one-year trial of lamivudine for chronic hepatitis B. Asia Hepatitis Lamivudine Study Group. N. Engl. J. Med. 1998, 339, 61-68.

25. Dienstag, J.L.; Schiff, E.R.; Wright, T.L.; Perrillo, R.P.; Hann, H.W.; Goodman, Z.; Crowther, L.; Condreay, L.D.; Woessner, M.; Rubin, M.; Brown, N.A. Lamivudine as initial treatment for chronic hepatitis B in the United States. N. Engl. J. Med. 1999, 341, 1256-1263. 
26. Marcellin, P.; Chang, T.T.; Lim, S.G.; Tong, M.J.; Sievert, W.; Shiffman, M.L.; Jeffers, L.; Goodman, Z.; Wulfsohn, M.S.; Xiong, S.; Fry, J.; Brosgart, C.L.; Adefovir Dipivoxil 437 Study Group. Adefovir dipivoxil for the treatment of hepatitis B e antigen-positive chronic hepatitis B. N. Engl. J. Med. 2003, 348, 808-816.

27. Chang, T.T.; Gish, R.G.; de Man, R.; Gadano, A.; Sollano, J.; Chao, Y.C.; Lok, A.S.; Han, K.H.; Goodman, Z.; Zhu, J.; Cross, A.; DeHertogh, D.; Wilber, R.; Colonno, R.; Apelian, D.; BEHoLD AI463022 Study Group. A comparison of entecavir and lamivudine for HBeAg-positive chronic hepatitis B. N. Engl. J. Med. 2006, 354, 1001-1010.

28. Lai, C.L.; Gane, E.; Liaw, Y.F.; Hsu, CW, Thongsawat, S.; Wang, Y.; Chen, Y.; Heathcote, E.J.; Rasenack, J.; Bzowej, N.; Naoumov, N.V.; Di Bisceglie, A.M.; Zeuzem, S.; Moon, Y.M.; Goodman, Z.; Chao, G.; Constance, B.F.; Brown, N.A.; Globe Study Group. Telbivudine versus lamivudine in patients with chronic hepatitis B. N. Engl. J. Med. 2007, 357, 2576-2588.

29. Marcellin, P.; Heathcote, E.J.; Buti, M.; Gane, E.; de Man, R.A.; Krastev, Z.; Germanidis, G.; Lee, S.S.; Flisiak, R.; Kaita, K.; Manns, M.; Kotzev, I.; Tchernev, K.; Buggisch, P.; Weilert, F.; Kurdas, O.O.; Shiffman, M.L.; Trinh, H.; Washington, M.K.; Sorbel, J.; Anderson, J.; SnowLampart, A.; Mondou, E.; Quinn, J.; Rousseau, F. Tenofovir disoproxil fumarate versus adefovir dipivoxil for chronic hepatitis B. N. Engl. J. Med. 2008, 359, 2442-2455.

30. Chang, T.T.; Lai, C.L.; Chien, R.N.; Guan, R.; Lim, S.G.; Lee, C.M.; Ng, K.Y.; Nicholls, G.J.; Dent, J.C.; Leung, N.W. Four years of lamivudine treatment in Chinese patients with chronic hepatitis B. J. Gastroenterol. Hepatol. 2004, 19, 1276-1282.

31. Leung, N.W.; Lai, C.L.; Chang, T.T.; Guan, R.; Lee, C.M.; Ng, K.Y.; Lim, S.G.; Wu, P.C.; Dent, J.C.; Edmundson, S.; Condreay, L.D.; Chien, R.N.; Asia Hepatitis Lamivudine Study Group. Extended lamivudine treatment in patients with chronic hepatitis B enhances hepatitis B e antigen seroconversion rates: results after 3 years of therapy. Hepatology 2001, 33, 1527-1532.

32. Sheldon, J.; Rodès, B.; Zoulim, F.; Bartholomeusz, A.; Soriano, V. Mutations affecting the replication capacity of the hepatitis B virus. J. Viral. Hep. 2006, 13, 427-434.

33. Doo, E.; Liang, J.T. Molecular anatomy and pathophysiologic implications of drug resistance in hepatitis B virus infection. Gastroenterology 2001, 120, 1000-1008.

34. Brunelle, M.N.; Jacquard, A.C.; Pichoud, C.; Durantel, D.; Carrouée-Durantel, S.; Villeneuve, J.P.; Trépo, C.; Zoulim, F. Susceptibility to antivirals of a human HBV strain with mutations conferring resistance to both lamivudine and adefovir. Hepatology 2005, 41, 1391-1398.

35. Zoulim, F. Mechanism of viral persistence and resistance to nucleoside and nucleotide analogs in chronic hepatitis B virus infection. Antiviral Res. 2004, 64, 1-15.

36. Locarnini, S.; Hatzakis, A.; Heathcote, J.; Keeffe, E.B.; Liang, T.J.; Mutimer, D.; Pawlotsky, J.M.; Zoulim, F. Management of antiviral resistance in patients with chronic hepatitis B. Antiviral Ther. 2004, 9, 679-693.

37. Keeffe, E.; Dieterich, D.T.; Han, S.H.B.; Jacobson, I.M.; Martin, P.; Schiff, E.R.; Tobias, H.; Wright, T.L. A treatment algorithm for the management of chronic hepatitis B virus infection in the United States. Clin. Gastroenterol. Hepatol. 2006, 2, 87-106.

38. Yuen, M.F.; Sablon, E.; Hui, C.K.; Yuan, H.J.; Decraemer, H.; Lai, C.L. Factors associated with hepatitis B virus DNA breakthrough in patients receiving prolonged lamivudine therapy. Hepatology 2001, 34, 785-791. 
39. Yuen, M.F.; Fong, D.Y.; Wong, D.K.; Yuen, J.C.; Fung, J.; Lai, C.L. Hepatitis B virus DNA levels at week 4 of lamivudine treatment predict the 5-year ideal response. Hepatology 2007, 46, 1695-1703.

40. Dienstag, J.L.; Cianciara, J.; Karayalcin, S.; Kowdley, K.V.; Willems, B.; Plisek, S.; Woessner, M.; Gardner, S.; Schiff, E. Durability of serologic response after lamivudine treatment of chronic hepatitis B. Hepatology 2003, 37, 748-755.

41. Song, B.C.; Suh, D.J.; Lee, H.C.; Chung, Y.H.; Lee, Y.S. Hepatitis B e antigen seroconversion after lamivudine therapy is not durable in patients with chronic hepatitis B in Korea. Hepatology 2000, 32, 803-806.

42. Lee, K.M.; Cho, S.W.; Kim, S.W.; Kim, H.J.; Hahm, K.B.; Kim, J.H. Effect of virological response on post-treatment durability of lamivudine-induced HBeAg seroconversion. J. Viral. Hep. 2002, 9, 208-212.

43. Liaw, Y.F.; Sung, J.J.; Chow, W.C.; Farrell, G.; Lee, C.Z.; Yuen, H.; Tanwandee, T.; Tao, Q.M.; Shue, K.; Keene, O.N.; Dixon, J.S.; Gray, D.F.; Sabbat, J.; Cirrhosis Asian Lamivudine Multicentre Study Group. Lamivudine for patients with chronic hepatitis B and advanced liver disease. N. Engl. J. Med. 2004, 351, 1521-1531.

44. Marcellin, P.; Chang, T.T.; Lim, S.G.; Sievert, W.; Tong, M.; Arterburn, S.; Borroto-Esoda, K.; Frederick, D.; Rousseau, F. Long-term efficacy and safety of adefovir dipivoxil for the treatment of hepatitis B e antigen-positive chronic hepatitis B. Hepatology 2008, 48, 750-758.

45. Gish, R.G.; Lok, A.S.; Chang, T.T.; De Man, R.A.; Gadano, A.; Sollano, J.; Han, H.H.; Chao, Y.C.; Lee, S.-D.; Harris, M.; Yang, J.; Colonno, R.; Brett-Smith, H. Entecavir Therapy for up to 96 Weeks in Patients With HBeAg-Positive Chronic Hepatitis B. Gastroenterology 2007;133:1437-1444

46. Colonno, R.J.; Rose, R.E.; Baldick, C.J.; Levine, S.M.; Klesczewski, K.; Tenney, D.J. High barrier to resistance results in no emergence of entecavir resistance in nucleoside-naïve subjects during the first two years of therapy. J. Hepatol. 2006, 44 (Suppl. 2), 182.

47. Tenney, D.J.; Rose, R.E.; Baldick, C.J.; Pokornowski, K.A.; Eggers, B.J.; Fang, J.; Wichroski, M.J.; Xu, D.; Yang, J.; Wilber, R.B.; Colonno, R.J. Long-term monitoring shows hepatitis B virus resistance to entecavir in nucleoside-naïve patients is rare through 5 years of therapy. Hepatology 2009, 49, 1503-1514.

48. Heathcote, E.; Gane, E.J.; deMan, R.A.; Chan, S.; Sievert, W.; Mauss, S.; Marcellin, P.; Sorbel, J.; Anderson, J.; Mondou, E.; Quinn, J.; Rousseau, F. Two year tenofovir Disoproxil Fumarate (TDF) Treatment and Adefovir Dipivoxil (ADV) switch data in HBeAg-positive patients with chronic hepatitis B (Study 103), preliminary analysis. Hepatology 2008, 48 (Supp. 1), 376A.

49. Zoulim, F.; Perrillo, R. Hepatitis B: reflections on the current approach to antiviral therapy. $J$. Hepatol. 2008, 48 (Suppl. 1), 2-19.

50. Manesis, E.K.; Hadziyannis, S.J. Interferon alpha treatment and retreatment of hepatitis B e antigen-negative chronic hepatitis B. Gastroenterology 2001, 121, 101-109.

51. Marcellin, P.; Lau, G.K.; Bonino, F.; Farci, P.; Hadziyannis, S.; Jin, R.; Lu, Z.M.; Piratvisuth, T.; Germanidis, G.; Yurdaydin, C.; Diago, M.; Gurel, S.; Lai, M.Y.; Button, P.; Pluck, N.; Peginterferon Alfa-2a HBeAg-Negative Chronic Hepatitis B Study Group. Peginterferon alfa-2a 
alone, lamivudine alone, and the two in combination in patients with HBeAg-negative chronic hepatitis B. N. Engl. J. Med. 2004, 351, 1206-1217.

52. Bonino, F.; Marcellin, P.; Lau, G.K.; Hadziyannis, S.; Jin, R.; Piratvisuth, T.; Germanidis, G.; Yurdaydin, C.; Diago, M.; Gurel, S.; Lai, M.Y.; Brunetto, M.R.; Farci, P.; Popescu, M.; McCloud, P.; Peginterferon Alfa-2a HBeAg-Negative Chronic Hepatitis B Study Group. Predicting response to peginterferon alpha-2a, lamivudine and the two combined for HBeAg-negative chronic hepatitis B. Gut 2007, 56, 699-705.

53. Marcellin, P.; Bonino, F.; Lau, G.K.; Farci, P.; Yurdaydin, C.; Piratvisuth, T.; Luo, K.; Gurel, S.; Hadziyannis, S.; Wang, Y.; Popescu, M.; Virological and biochemical response in patients with HBeAg-negative CHB treated with peginterferon alfa-2a (40KD) + lamivudine: 3-year follow-up results. J. Hepatol. 2007, 46 (Suppl. 1), 25-26.

54. Hadziyannis, S.J.; Papatheodoridis, G.V.; Dimou, E.; Laras, A.; Papaioannou, C. Efficacy of longterm lamivudine monotherapy in patients with hepatitis B e antigen-negative chronic hepatitis B. Hepatology 2000, 32, 847-851.

55. Tassopoulos, N.C.; Volpes, R.; Pastore, G.; Heathcote, J.; Buti, M.; Goldin, R.D.; Hawley, S.; Barber, J.; Condreay, L.; Gray, D.F. Post lamivudine treatment follow up of patients with $\mathrm{HBeAg}$ negative chronic hepatitis B. J. Hepatol. 1999, 30 (Suppl. 1), 117.

56. Santantonio, T.; Mazzola, M.; Iacovazzi, T.; Miglietta, A.; Guastadisegni, A.; Pastore, G. Long-term follow-up of patients with anti-HBe/HBV DNA-positive chronic hepatitis B treated for 12 months with lamivudine. J. Hepatol. 2000, 32, 300-306.

57. Hadziyannis, S.J.; Tassopoulos, N.C.; Heathcote, E.J.; Chang, T.T.; Kitis, G.; Rizzetto, M.; Marcellin, P.; Lim, S.G.; Goodman, Z.; Wulfsohn, M.S.; Xiong, S.; Fry, J.; Brosgart, C.L.; Adefovir Dipivoxil 438 Study Group. Adefovir dipivoxil for the treatment of hepatitis B antigennegative chronic hepatitis B. N. Engl. J. Med. 2003, 348, 800-807.

58. Hadziyannis, S.J.; Tassopoulos, N.C.; Heathcote, E.J.; Chang, T.T.; Kitis, G.; Rizzetto, M.; Marcellin, P.; Lim, S.G.; Goodman, Z.; Ma, J.; Brosgart, C.L.; Borroto-Esoda, K.; Arterburn, S.; Chuck, S.L.; Adefovir Dipivoxil 438 Study Group. Long-term therapy with adefovir dipivoxil for HBeAg-negative chronic hepatitis B for up to 5 years. Gastroenterology 2006, 131, 1743-1751.

59. Hadziyannis, S.; Sevastianos, V.; Rapti, I.N.; Tassopoulos, N. Sustained biochemical and virological remission after discontinuation of 4 to 5 years of adefovir dipivoxil (ADV) treatment in HBeAg negative chronic hepatitis B. Hepatology 2006, 44, $231 \mathrm{~A}$.

60. Lai, C.L.; Shouval, D.; Lok, A.S.; Chang, T.T.; Cheinquer, H.; Goodman, Z.; DeHertogh, D.; Wilber, R.; Zink, R.C.; Cross, A.; Colonno, R.; Fernandes, L.; BEHoLD AI463027 Study Group. Entecavir versus lamivudine for patients with HBeAg-negative chronic hepatitis B. N. Engl. J. Med. 2006, 354, 1011-1020.

61. Shouval, D.; Akarca, U.S.; Hatzis, G.; Kitis, G.; Lai, C.L.; Cheinquer, H.; Chang, T.T.; Zinc, R.; Zhu, J.; Brett-Smith, H. Continued virologic and biochemical improvement through 96 weeks of entecavir treatment in $\mathrm{HBeAg}(-)$ chronic hepatitis B patients (Study ETV-027). J. Hepatol. 2006, 44, S21.

62. Lai, C.L.; Gane, E.; Hsu, C.W.; Thongsawat, S.; Wang, Y.; Chen, Y.; Heathcote, E.J.; Rasenack, J.; Bzowej, N.; Naoumov, N.; Zeuzem, S.; Di Bisceglie, A.; Chao, G.C.; Fielman, B.A.; Brown, N.A.; Study Group Globe. Two-year results from the Globe trial in patients with hepatitis B: 
greater clinical and antiviral efficacy for Telbivudine (LdT) vs. Lamivudine. Hepatology 2006, 44, 222A.

63. Di Bisceglie, A.; Lai, C.L.; Gane, E.; Chen, Y.; Thongsawat, S.; Wang, Y.; Heathcote, E.J.; Zeuzem, S.; Rasenack, J.; Bzowej, N.; Han, S.H.; Naoumov, N.; Hwang, S.G.; Lim, S.G.; Chao, G.C.; Fielman, B.A..; Brown, N.A.; Study Group Globe The GLOBE16; $1^{\text {St }}$ Telbivudine Globe trial: maximal early HBV suppression is predictive of optimal two-year efficacy in nucleosidetreated hepatitis B patients. Hepatology 2006, 44, 230A.

64. Marcellin, P.; Buti, M.; Krastev, M.; Gurel, S.; Balabanska, R.I.; Dusheiko, G.; Myers, R.P.; Heathcote, E.J.; Sorbel, J.; Anderson, E.; Mondou, E.; Rousseau, F. Two Year Tenofovir Disoproxil Fumarate (TDF) Treatment and Adefovir Dipivoxil (ADV) Switch Data in HBeAgNegative Patients with Chronic Hepatitis B (Study 102), Preliminary Analysis. Hepatology 2008, $48,370 \mathrm{~A}$

65. Zoulim, F. Combination of nucleoside analogues in the treatment of chronic hepatitis B infection: lesson from experimental models. J. Antimic. Chemoter. 2005, 55, 608-611.

66. Westland, C.E.; Yang, H.; Delaney, W.E. 4th; Wulfsohn, M.; Lama, N.; Gibbs, C.S.; Miller, M.D.; Fry, J.; Brosgart, C.L.; Schiff, E.R.; Xiong, S. Activity of adefovir dipivoxil against all patterns of lamivudine-resistant hepatitis B viruses in patients. J. Viral Hepat. 2005, 12, 67-73.

67. Angus, P.; Vaughan, R.; Xiong, S.; Yang, H.; Delaney, W.; Gibbs, C.; Brosgart, C.; Colledge, D.; Edwards, R.; Ayres, A.; Bartholomeusz, A.; Locarnini, S. Resistance to adefovir dipivoxil therapy associated with the selection of a novel mutation in the HBV polymerase. Gastroenterology 2003, 125, 292-297.

68. Villeneuve, J.P.; Durantel, D.; Durantel, S.; Westland, C.; Xiong, S.; Brosgart, C.L.; Gibbs, C.S.; Parvaz, P.; Werle, B.; Trépo, C.; Zoulim, F. Selection of a hepatitis B virus strain resistant to adefovir in a liver transplantation patient. J. Hepatol. 2003, 39, 1085-1089.

69. Lampertico, P.; Viganò, M.; Manenti, E.; Iavarone, M.; Sablon, E.; Colombo, M. Low resistance to adefovir combined with lamivudine: a 3-year study of 145 lamivudine resistant hepatitis B patients. Gastroenterology 2007, 133, 1445-1451.

70. Nguyen, M.H.; Keeffe, E.B. Chronic hepatitis B: early viral suppression and long-term outcomes of therapy with oral nucleos(t)ides. J. Viral Hepat. 2009, 16, 149-55.

71. Rapti, I.; Dimou, E.; Mitsoula, P.; Hadziyannis, S.J. Adding-on versus switching-to adefovir therapy in lamivudine-resistant HBeAg-negative chronic hepatitis B. Hepatology 2007, 45, 307313.

72. Lampertico, P.; Marzano, A.; Levrero, M.; Santantonio, T.; Di Marco, V.; Brunetto M.; Andreone P.; Sagnelli, E.; Fagiuoli, S.; Mazzella, G.; Raimondo, G.; Gaeta, G.; Ascione, A. on behalf of the Italian Association for the Study of the Liver (AISF). Adefovir and lamivudine combination therapy is superior to adefovir monotherapy for lamivudine-resistant patients with $\mathrm{HBeAg}$ negative chronic hepatitis B. J. Hepatol. 2007, 46, S191.

73. Lampertico, P.; Viganò, M.; Manenti, E.; Iavarone, M.; Lunghi, G.; Colombo, M. Adefovir rapidly suppresses hepatitis $\mathrm{B}$ in $\mathrm{HBeAg-negative} \mathrm{patients} \mathrm{developing} \mathrm{genotypic} \mathrm{resistance} \mathrm{to}$ lamivudine. Hepatology 2005, 42, 1414-1419.

74. Benhamou, Y.; Thibault, V.; Vig, P.; Calvez, V.; Marcelin, A.G.; Fievet, M.H.; Currie, G.; Chang, C.G.; Biao, L.; Xiong, S.; Brosgart, C.; Poynard, T. Safety and efficacy of adefovir 
dipivoxil in patients infected with lamivudine-resistant hepatitis B and HIV-1. J. Hepatol. 2006, $44,62-67$.

75. Yatsuji, H.; Suzuki, F.; Sezaki, H.; Akuta, N.; Suzuki, Y.; Kawamura, Y.; Hosaka, T.; Kobayashi, M.; Saitoh, S.; Arase, Y.; Ikeda, K.; Watahiki, S.; Iwasaki, S.; Kobayashi, M.; Kumada, H. Low risk of adefovir resistance in lamivudine-resistant chronic hepatitis B patients treated with adefovir plus lamivudine combination therapy: two-year follow-up. J. Hepatol. 2008, 48, 923931.

76. Lampertico, P.; Viganò, M.; Facchetti, F.; Iavarone, M.; Colombo, M.. Four years of Adefovir add-on in 145 lamivudine resistant patients with chronic hepatitis B: low risk of genotypic resistance to ADV and prevention of virologic breakthrough. Hepatology 2008, 48, 712A

77. Hadziyannis, S.J.; Costamena, A.; Laras, A.; Hadziyannis, E. Predictors/determinants of sustained virological response (SVR) and of HBsAg loss following long term adefovir dipivoxil (ADV) therapy in HBeAg-negative chronic hepatitis B (CHB). Hepatology 2008, 48, 896A.

78. Villet, S.; Pichoud, C.; Villeneuve, J.P.; Trépo, C.; Zoulim, F. Selection of a multiple drugresistant hepatitis B virus strain in a liver-transplanted patient. Gastroenterology 2006, 131, 1253 1261.

79. Keeffe, E.B.; Zeuzem, S.; Koff, R.S.; Dieterich, D.T.; Esteban-Mur, R.; Gane, E.J.; Jacobson, I.M.; Lim, S.G.; Naoumov, N.; Marcellin, P.; Piratvisuth, T.; Zoulim, F. Report of an international workshop: Roadmap for management of patients receiving oral therapy for chronic hepatitis B. Clin. Gastroenterol. Hepatol. 2007, 5, 890-897.

80. Armstrong, G.L.; Wasley, A.; Simard, E.P.; McQuillan, G.M.; Kuhnert, W.L.; Alter, M.J. The prevalence of hepatitis C virus infection in the United States, 1999 through 2002. Ann. Intern. Med. 2006, 144, 705-714.

81. Esteban, J.I.; Sauleda, S.; Quer, J. The changing epidemiology of hepatitis C virus infection in Europe. J. Hepatol. 2008, 48, 148-162.

82. Bosetti, C.; Levi, F.; Lucchini, F.; Zatonski, W.A.; Negri, E.; La Vecchia, C. Worldwide mortality from cirrhosis: an update to 2002. J. Hepatol. 2007, 46, 827-839.

83. Sangiovanni, A.; Prati, G.M.; Fasani, P.; Ronchi, G.; Romeo, R.; Manini, M.; Del Ninno, E.; Morabito, A.; Colombo M. The natural history of compensated cirrhosis due to hepatitis $\mathrm{C}$ virus: a 17-year cohort study of 214 patients. Hepatology 2006, 43, 1303-1310.

84. Hoofnagle, J.H.; Mullen, K.D.; Jones, D.B.; Rustgi, V.; Di Bisceglie, A.; Peters, M.; Waggoner, J.G.; Park, Y.; Jones, E.A. Treatment of chronic non-A, non-B hepatitis with recombinant human alpha interferon. A preliminary report. N. Engl. J. Med. 1986, 315, 1575-1578.

85. Poynard, T.; Marcellin, P.; Lee, S.S.; Niederau, C.; Minuk, G.S.; Ideo, G.; Bain, V.; Heathcote, J.; Zeuzem, S.; Trepo, C.; Albrecht, J. Randomised trial of interferon alpha2b plus ribavirin for 48 weeks or for 24 weeks versus interferon alpha2b plus placebo for 48 weeks for treatment of chronic infection with hepatitis $\mathrm{C}$ virus. International Hepatitis Interventional Therapy Group (IHIT). Lancet 1998, 352, 1426-1432.

86. McHutchison, J.G.; Gordon, S.C.; Schiff, E.R.; Shiffman, M.L.; Lee, W.M.; Rustgi, V.K.; Goodman, Z.D.; Ling, M.H.; Cort, S.; Albrecht, J.K. Interferon alfa-2b alone or in combination with ribavirin as initial treatment for chronic hepatitis C. Hepatitis Interventional Therapy Group. N. Engl. J. Med. 1998, 339, 1485-1492. 
87. Feld, J.J.; Hoofnagle, J.H. Mechanism of action of interferon and ribavirin in treatment of hepatitis C. Nature 2005, 436, 967-972.

88. Harris, J.M.; Martin, N.E.; Modi, M. Pegylation: a novel process for modifying pharmacokinetics. Clin. Pharmacokinet. 2001, 40, 539-551.

89. Glue, P.; Fang, J.W.; Rouzier-Panis, R.; Raffanel, C.; Sabo, R.; Gupta, S.K.; Salfi, M.; Jacobs, S. Pegylated interferon-alpha-2b: pharmacokinetics, pharmacodynamics, safety and preliminary efficacy data. Clin. Pharmacol. Ther. 2000, 68, 556-567.

90. Bailon, P.; Palleroni, A.; Schaffer, C.A.; Spence, C.L.; Fung, W.J.; Porter, J.E.; Ehrlich, G.K.; Pan, W.; Xu, Z.X.; Modi, M.W.; Farid, A.; Berthold, W.; Graves, M. Rational design of a potent, long-lasting form of interferon: a $40 \mathrm{KDa}$ branched polyethylene glycol-conjugated interferon alpha-2a for the treatment of hepatitis C. Bioconjug. Chem. 2001, 12, 195-202.

91. Manns, M.P.; McHutchison, J.G.; Gordon, S.C.; Rustgi, V.K.; Shiffman, M.; Reindollar, R.; Goodman, Z.D.; Koury, K.; Ling, M.; Albrecht, J.K. Peginterferon alfa-2b plus ribavirin compared with interferon alfa- $2 \mathrm{~b}$ plus ribavirin for initial treatment of chronic hepatitis $\mathrm{C}$ : a randomised trial. Lancet 2001, 358, 958-965.

92. Fried, M.W.; Shiffman, M.L.; Reddy, K.R.; Smith, C.; Marinos, G.; Goncales, F.L.; Haussinger, D.; Diago, M.; Carosi, G.; Dhumeaux, D.; Craxi, A.; Lin, A.; Hoffman, J.; Yu, J. Peginterferon alfa-2a plus ribavirin for chronic hepatitis C virus infection. N. Engl. J. Med. 2002, 347, 975-982.

93. Caliceti, P. Pharmacokinetics of pegylated interferons: what is misleading? Dig. Liver Dis. 2004, 36 (Suppl. 3), 334-339.

94. Bruno, R.; Sacchi, P.; Ciappina, V.; Zocchetti, C.; Patruno, S.; Maiocchi, L.; Filice, G. Viral dynamics and pharmacokinetics of peginterferon alpha-2a and peginterferon alpha-2b in naïve patients with chronic hepatitis C: a randomized, controlled study. Antivir. Ther. 2004, 9, 491-497.

95. Silva, M.; Poo, J.; Wagner, F.; Jackson, M.; Cutler, D.; Grace, M.; Bordens, R.; Cullen, C.; Harvey, J.; Laughlin, M. A randomised trial to compare the pharmacokinetic, pharmacodynamic, and antiviral effects of peginterferon alfa- $2 \mathrm{~b}$ and peginterferon alfa- $2 \mathrm{a}$ in patients with chronic hepatitis C (COMPARE). J. Hepatol. 2006, 45, 204-213.

96. Di Bisceglie, A.M.; Ghalib, R.H.; Hamzeh, F.; Rustgi, V.K. Early virologic response after peginterferon alpha-2a plus ribavirin or peginterferon alpha- $2 \mathrm{~b}$ plus ribavirin treatment in patients with chronic hepatitis C. J. Viral Hep. 2007, 14, 721-729.

97. Rumi, M.G.; Aghemo, A.; Prati, G.M.; D’Ambrosio, R.; Donato, M.F.; Russo, A.; Cerami, N.; Soffredini, R.; Colombo M. Randomized study comparing peginterferon-alfa2a plus ribavirin and peginterferon-alfa2b plus ribavirin in naïve patients with chronic hepatitis $\mathrm{C}$ : final results of the Milan safety tolerability (MIST) study. Hepatology 2008, 48 (Suppl.) 404A.

98. Ascione, A.; De Luca, M.; Tartaglione, M.T.; Lampasi, F.; Galeota Lanza, A.; Picciotto, F.P.; Di Costanzo, G.G.; Leandro, G. Peginterferon alpha-2a plus ribavirin versus Peginterferon alpha-2b plus ribavirin in naïve patients with chronic hepatitis $\mathrm{C}$ virus infection: results of a prospective randomised trial. J. Hepatol. 2008, 48 (Suppl. 2), 370.

99. Sulkowski, E.; Lawitz, M.L.; Shiffman, M.L.; Muir, A.J.; Galler, G.; McCone, J.; Nyberg, L.; Lee, W.M.; Ghalib, R.; Schiff, E.; Galati, J.; Bacon, B.; Davis, M.; Mukhopadhyay, P.; NOviello, S.; Pedicone, L.; Albrecht, J.; McHutchison, J. Final results of the ideal (individualized dosing 
efficacy versus flat dosing to assess optimal pegylated interferon therapy) phase IIIB study. $J$. Hepatol. 2008, 48 (Suppl. 2), 370.

100. Jacobson, I.M.; Brown, R.S.; Freilich, B.; Afdhal, N.; Kwo, P.J.; Santoro, J.; Becker, S.; Wakil, A.E.; Pound, D.; Godofsky, E.; Strauss, R.; Bernstein, D.; Flamm, S.; Pauly, M.P.; Mukhopadhyay, P.; Griffel, L.H.; Brass, C.A.; WIN-R Study Group. Peginterferon alfa-2b and weight-based of flat-dose ribavirin in Chronic hepatitis C Patients: a randomized trial. Hepatology 2007, 46, 971-981.

101. Zeuzem, S.; Hultcrantz, R.; Bourliere, M.; Goeser, T.; Marcellin, P.; Sanchez-Tapias, J.; Sarrazin, C.; Harvey, J.; Brass, C.; Albrecht, J. Peginterferon alpha-2b plus ribavirin for treatment of chronic hepatitis $\mathrm{C}$ in previously untreated patients infected with $\mathrm{HCV}$ genotypes 2 or 3. J. Hepatol. 2004, 40, 993-999.

102. Davis, G.L.; Wong, J.B.; McHutchison, J.G.; Manns, M.P.; Harvey, J.; Albrecht, J. Early virological response to treatment with peginterferon alfa- $2 \mathrm{~b}$ plus ribavirin in patients with chronic hepatitis C. Hepatology 2003, 38, 645-652.

103. Ghany, M.G.; Strader, D.B.; Thomas, D.L.; Seeff, L.B. Diagnosis, management, and treatment of hepatitis C: an update. Hepatology 2009, 49, 1335-1374.

104. Ferenci, P.; Fried, M.W.; Shiffman, M.L.; Smith, C.I.; Marinos, G.; Goncales, F.R. Jr.; Haussinger, D.; Diago, M.; Carosi, G.; Dhumeaux, D.; Craxì, A.; Chaneac, M.; Reddy, K.R. Predicting sustained virological responses in chronic hepatitis $\mathrm{C}$ patients treated with peginterferon alfa-2a (40 KD)/ribavirin. J. Hepatol. 2005, 43, 425-433.

105. Dalgard, O.; Bjøro, K.; Hellum, K.B.; Myrvang, B.; Ritland, S.; Skaug, K.; Raknerud, N.; Bell, H. Treatment with pegylated interferon and ribavirin in HCV infection with genotype 2 or 3 for 14 weeks: a pilot study. Hepatology 2004, 40, 1260-1265

106. Zeuzem, S.; Buti, M.; Ferenci, P.; Sperl, J.; Horsmans, Y.; Cianciara, J.; Ibranyi, E.; Weiland, O.; Noviello, S.; Brass, C.; Albrecht, J. Efficacy of 24 weeks treatment with peginterferon alfa-2b plus ribavirin in patients with chronic hepatitis $\mathrm{C}$ infected with genotype 1 and low pretreatment viremia. J. Hepatol. 2006, 44, 97-103.

107. Jensen, D.M.; Morgan, T.R.; Marcellin, P.; Pockros, P.J.; Reddy, K.R.; Hadziyannis, S.J.; Ferenci, P.; Ackrill, A.M.; Willems, B. Early identification of HCV genotype 1 patients responding to 24 weeks peginterferon alpha-2a (40 kd)/ribavirin therapy. Hepatology 2006, 43, 954-960.

108. Mangia, A.; Santoro, R.; Minerva, N.; Ricci, G.L.; Carretta, V.; Persico, M.; Vinelli, F.; Scotto, G.; Bacca, D.; Annese, M.; Romano, M.; Zechini, F.; Sogari, F.; Spirito, F.; Andriulli, A. Peginterferon alfa-2b and ribavirin for 12 vs. 24 weeks in HCV genotype 2 or 3. N. Engl. J. Med. 2005, 352, 2609-2617.

109. von Wagner, M.; Huber, M.; Berg, T.; Hinrichsen, H.; Rasenack, J.; Heintges, T.; Bergk, A.; Bernsmeier, C.; Haussinger, D.; Herrmann, E.; Zeuzem, S. Peginterferon-alpha-2a (40KD) and ribavirin for 16 or 24 weeks in patients with genotype 2 or 3 chronic hepatitis C. Gastroenterology 2005, 129, 522-527.

110. Shiffman, M.L.; Suter, F.; Bacon, B.R.; Nelson, D.; Harley, H.; Solà, R.; Shafran, S.D.; Barange, K.; Lin, A.; Soman, A.; Zeuzem, S.; ACCELLERATE Investigators. Peginterferon alfa-2a and ribavirin for 16 or 24 weeks in HCV genotype 2 or 3. N. Engl. J. Med. 2007, 357, 124-134. 
111. Lagging, M.; Langeland, N.; Pedersen, C.; Färkillä, M.; Buhl, M.R.; Mørch, K.; Dhillon, A.P.; Alsiø, A.; Hellstrand, K.; Westin, J.; Norkrans, G.; NORDynamiC Study Group. Randomized comparison of 12 or 24 weeks of peginterferon alpha-2a and ribavirin in chronic hepatitis $\mathrm{C}$ virus genotype 2/3 infection. Hepatology 2008, 47, 1837-1845.

112. Dalgard, O.; Bjøro, K.; Ring-Larsen, H.; Bjornsson, E.; Holberg-Petersen, M.; Skovlund, E.; Reichard, O.; Myrvang, B.; Sundeløf, B.; Ritland, S.; Hellum, K.; Fridén, A.; Florholmen, J.; Verbaan, H.; North-C Group. Pegylated interferon alfa and ribavirin for 14 versus 24 weeks in patients with hepatitis $\mathrm{C}$ virus genotype 2 or 3 and rapid virological response. Hepatology 2008, 47, 35-42.

113. Mangia, A.; Minerva, N.; Bacca, D.; Cozzolongo, R.; Agostinacchio, E.; Sogari, F.; Scotto, G.; Vinelli, F.; Ricci, G.L.; Romano, M.; Carretta, V.; Petruzzellis, D.; Andriulli, A. Determinants of relapse after a short (12 weeks) course of antiviral therapy and re-treatment efficacy of a prolonged course in patients with chronic hepatitis $\mathrm{C}$ virus genotype 2 or 3 infection. Hepatology 2009, 49, 358-363.

114. Berg, T.; von Wagner, M.; Nasser, S.; Sarrazin, C.; Heintges, T.; Gerlac, T.; Buggisch, P.; Goeser, T.; Rasenack, J.; Pape, G.R.; Schmidt, W.E.; Kallinowski, B.; Klinker, H.; Spengler, U.; Martus, P.; Aishuth, U.; Zeuzem, S. Extended treatment duration for hepatitis C virus type 1: comparing 48 versus 72 weeks of peginterferon-alfa-2a plus ribavirin. Gastroenterology 2006, 130, 10861097.

115. Pearlman, B.L.; Ehleben, C.; Saifee, S. Treatment extension to 72 weeks of peginterferon and ribavirin in hepatitis c genotype 1-infected slow responders. Hepatology 2007, 46, 1688-1694.

116. Buti, M.; Lurie, Y.; Zakharova, N.G.; Blokhina, N.P.; Horban, A.; Sarrazin, C.; Balciuniene, L.; Chen, R.; Yu, X.; Faruqi, R.; Esteban, R. Extended treatment duration in chronic hepatitis C genotype 1-infected slow responders: final results of the SUCCESS study. J. Hepatol. 2009, 50 (Suppl. 1), 58.

117. McHutchison, J.G.; Bartenschlager, R.; Patel, K.; Pawlotsky, J.M. The face of future hepatitis C antiviral drug development: recent biological and virologic advances and their translation to drug development and clinical practice. J. Hepatol. 2006, 44, 411-421.

118. Shiffman, M.L.; Di Bisceglie, A.M.; Lindsay, K.L.; Norishima, C.; Wright, E.C.; Everson, G.T.; Lok, A.S.; Morgan, T.R.; Bonkovsky, H.L.; Lee, W.M.; Dienstag, J.L.; Ghany, M.G.; Goodman, Z.D.; Everhart, J.E. Hepatitis C Antiviral Long-Term Treatment Against Cirrhosis Trial Group. Peginterferon alfa-2a and ribavirin in patients with chronic hepatitis $\mathrm{C}$ who have failed prior treatment. Gastroenterology 2004, 126, 1015-1023.

119. Poynard, T.; Colombo, M.; Bruix, J.; Schiff, E.; Terg, R.; Flamm, S.; Moreno-Otero, R.; Carrilho, F.; Schmidt, W.; Berg, T.; McGarrity, T.; Heathcote, E.J.; Goncales, F.; Diago, M.; Craxì, A.; Silva, M.; Bedossa, P.; Mukhopadhyay, P.; Griffel, L.; Burroughs, M.; Brass, C.; Albrecht, J.; Epic Study Group. Peginterferon alfa-2b and ribavirin: effective in patients with hepatitis $\mathrm{C}$ who failed interferon alfa/ribavirin therapy. Gastroenterology 2009, 136, 1618-1628.

120. Jensen, D.M.; Marcellin, P.; Freilich, B.; Andreone, P.; Di Bisceglie, A.; Brandão-Mello, C.E.; Reddy, K.R.; Craxì, A.; Martin, A.O.; Teuber, G.; Messinger, D.; Thommes, J.A.; Tietz, A. Retreatment of patients with chronic hepatitis $\mathrm{C}$ who do not respond to peginterferon-alpha2b: a randomized trial. Ann. Intern. Med. 2009, 150, 528-540. 
121. Hézode, C.; Forestier, N.; Dusheiko, G.; Ferenci, P.; Pol, S.; Goeser, T.; Bronowicki, J.P.; Bourlière, M.; Gharakhanian, S.; Bengtsson, L.; McNair, L.; George, S.; Kieffer, T.; Kwong, A.; Kauffman, R.S.; Alam, J.; Pawlotsky, J.M.; Zeuzem, S.; PROVE2 Study Team. Telaprevir and peginterferon with or without ribavirin for chronic HCV infection.. N. Engl. J. Med. 2009, 360, 1839-1850.

122. Kwo, P.; Lawitz, E.; McCone, J.; Schiff, E.; Vierling, J.; Pound, D.; Davis, M.; Galati, J.; Gordon, S.; Ravendhran, N.; Rossaro, L.; Anderson, F.; Jacobson, I.; Rubin, R.; Koury, K.; Brass, C.; Chaudhri, E.; Albrecht, J. HCV-SPRINT 1 final results: SVR 24 from a phase II study of Boceprevir plus PegIntron (PegIFN-alfa2b)/Ribavirin in treatment-naïve subjects with genotype 1 chronic hepatitis C. J. Hepatol. 2009, 50 (Suppl. 1), 4.

(C) 2009 by the authors; licensee Molecular Diversity Preservation International, Basel, Switzerland. This article is an open-access article distributed under the terms and conditions of the Creative Commons Attribution license (http://creativecommons.org/licenses/by/3.0/). 